\title{
Potential secondary events caused by early Holocene paleoearthquakes in Fennoscandia - a climate-related review
}

\author{
Olav Eldholm ${ }^{1} \&$ Hilmar Bungum² \\ ${ }^{1}$ Department of Earth Science, University of Bergen, Norway \\ ${ }^{2}$ St. Georgsvei 53, N-2080 Oslo, Norway \\ E-mail corresponding author (HilmarBungum): hilmar.bungum@gmail.com
}

\section{Keywords:}

- Fennoscandia

- Early Holocene seismicity

- Glacial Isostatic Adjustment

- Greater Lapland Fault Province

- Climate

- Glacially Induced Faults
During the last deglaciation of Fennoscandia, large earthquakes may have induced secondary effects on the high-latitude coastal regions and continental margins primarily from surface rock avalanches, large and small submarine slides, local and regional flooding, and tsunamis. In this overview, we show that the climate-earthquake-slide-tsunami causal sequence is particularly important, as is structural inheritance and rejuvenation. However, there are potential earthquake-generating early Holocene faults also beyond the previously defined Lapland Fault Province. Thus, we introduce the term the Greater Lapland Fault Province. Earthquakes in the expanded fault province are candidates for triggering the $8.1 \mathrm{ka}$ Storegga Megaslide and/or its predecessors and coeval tsunamis. The events might have released other submarine slides, gas hydrate expulsion leaving large pockmark fields and rock avalanches and submarine mass wasting in fjord and lake settings. Moreover, seismic events may also have triggered local and regional flooding by breakup of ice and sediment barriers.

\section{Introduction}

27. September 2020

Accepted:

19. April 2021

Published online:

7. June 2021
Except for the western Caledonide Orogen (Fig. 1), most of Fennoscandia is a craton comprising Archaean and Proterozoic rocks, underlain by thick lithosphere. The occurrence of early Holocene paleoearthquakes in Fennoscandia has been summarised by Lagerbäck \& Sundh (2008), who located the events in an approximately $400 \times 400 \mathrm{~km}$ region north of the Gulf of Bothnia denoted the Lapland Fault Province (LFP). However, the existence of events also beyond the LFP have led us to introduce the term Greater Lapland Fault Province (GLFP) for the region in which deglaciation contributed to the early Holocene seismicity (Fig. 1). The GLFP includes the northern and central parts of Sweden and Finland, as well as the neighbouring regions of Norway and Russia. In particular, the terms Glacially Triggered Faulting and Glacially Induced Faulting (GIF) have been applied to these events (Steffen et al., in press), and the consensus is that the events relate to much older faults rejuvenated during crustal uplift following the last deglaciation, thus of a climatic origin. Nonetheless, a number of questions remain unanswered, 


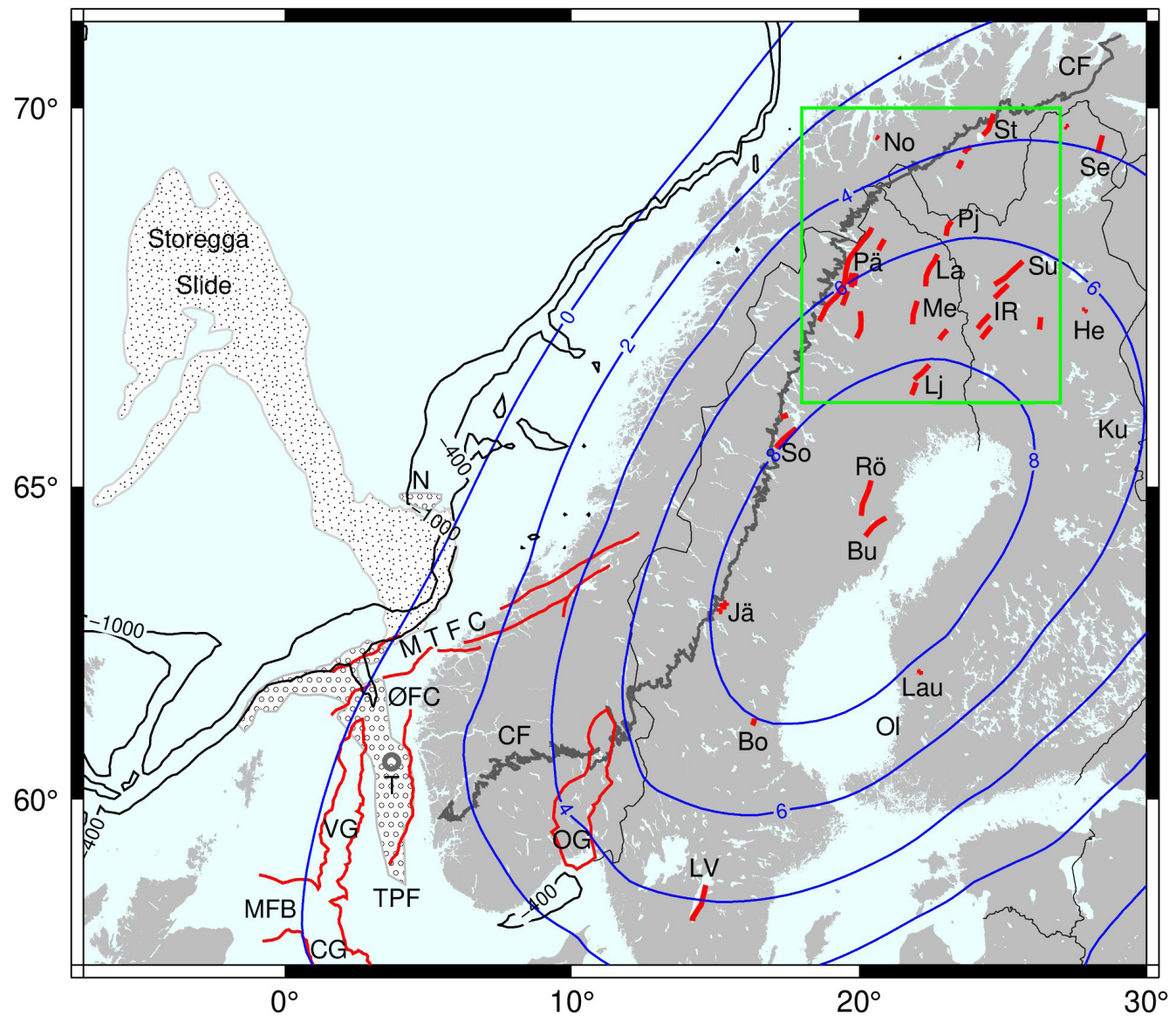

Fig. 1. Early Holocene postglacial faults and fault complexes in the Greater Lapland Fault Province (GLFP) where the green box outlines the approximate ( $400 \times 400 \mathrm{~km}$ ) LFP of Lagerback \& Sundh (2008). The onshore faults are based on Olesen et al. (in press) and Posiva (2019), whereas the offshore structures are from the NPD database (2020). GIFs: Bo, Bollnäs; Bu, Burträsk; He: Helukka; IR, Isovaara-Riikonkumpu; Jä, Jämtland; La, Laino; Lau, Lauhanvuori; Lj, Lansjärv; LV, Lake Vättern; Me, Merasjärvi; No, Normannvikdalen; Pj, Palojärvi; Pä, Pärvie; Rö, Röjnoret; Se, Sevettjärvi; So, Sorsele; St, Stuoragurra; Su, Suasselkä. Also shown are some other structural features (CG, Central Graben; MFB, Moray Firth Basin; VG, Viking Graben; $\varnothing F G, \varnothing y g a r d e n$ Fault Zone; MTFC, Møre-Trøndelag Fault Complex; OG, Oslo Graben). T refers to the Troll gas field. and we show outlines of the 8.1 ka Storegga Slide; N, Nyegga Pockmark Field; TPF, Troll Pockmark Field. Also shown are the Finnish regions Kuusamo, Ku, and Olkiluoto, Ol; and contours of present rate of postglacial uplift (mm/yr) from Vestøl et al. (2019). Bathymetry in metres. Caledonian Front, CF, from Olesen et al. (in press).

in particular concerning the modelling of the Glacial Isostatic Adjustment (GIA). This includes the commonly assumed simplification of the known lateral variation of physical properties in the lithosphere and upper asthenosphere (Vestøl, 2006; Vestøl et al., 2019; Li et al., 2020), as well as the apparent large lateral variability of the Fennoscandian Ice Sheet (FIS; Lane et al., 2020). Noteworthy, however, Lund et al. (2009) did include a 3D varying lithospheric thickness in their Fennoscandian model. Moreover, the marked difference in postglacial tectonic response between $\mathrm{N}$ America and Fennoscandia is not yet satisfactorily explained (Eldholm \& Bungum, in prep).

In addition to the well-documented paleoearthquakes north of $64^{\circ} \mathrm{N}$, Fig. 1 also includes three structures farther south which are less well known, namely the Jämtland Fault ( $63.1^{\circ} \mathrm{N}, 15.1^{\circ} \mathrm{E}$; Mikko et al., 2015; Berglund \& Dahlström, 2015), the Bollnäs Fault ( $61.3^{\circ} \mathrm{N}, 16.3^{\circ} \mathrm{E}$; Schmidt et al., 2014), and the Lake Vättern Fault ( $58.1^{\circ} \mathrm{N}, 14.4^{\circ} \mathrm{E}$; Jakobsson et al., 2014). Within the study region in Fig. 1 we also find the huge Storegga Slide (Bugge et al., 1987; Solheim et al., 2005a) and the Troll pockmark field (Mazzini et al., 2017). As a frame-of-reference for the spectacular postglacial phenomena we have also included the NKG2016LU_lev model of the present uplift rates from the Nordic Commission of Geodesy (Vestøl et al., 2019), where the levelling is relative to a GIA-induced geoid model. However, in the present context the difference between this model and the absolute (empirical) one is negligible. 
It is likely that the GLFP paleoearthquakes initiated secondary phenomena which in some cases may have been catastrophic. Accepting a climatic relationship, we first briefly summarise the early Holocene climate, paleoearthquakes, LFP and GLFP. Then, we review some secondary relationships potentially initiated by the early Holocene paleoearthquake activity in the GLFP in a climate-related context. These include the Storegga Slide and its predecessors and coeval submarine slides elsewhere along the Norwegian continental margin, as well as other forms of mass wasting, rock avalanches, local and regional flooding, and gas hydrate release creating large pockmark fields.

While our work may appear as a review paper, it is primarily an effort to collate and interpret available multidisciplinary geodata within a climatic framework with the purpose to better understand secondary, and possibly interconnected, phenomena.

\section{Early Holocene environment}

The early Holocene, $11.63-7 \mathrm{ka}^{1}$, is a time of major environmental change (Wanner et al., 2008; Carlson \& Clark, 2012) when most of the huge Fennoscandian continental ice sheet was removed. The ice sheet diminished in lateral extent and volume during the last deglaciation in response to Holocene warming (Siegert et al., 2001). Towards the end of the glacial cycle, the ice masses had melted and retreated, waxing and waning by short-term temperature changes. Field-based ${ }^{14} \mathrm{C}$ ice-margin chronologies exist in Fennoscandia (Hughes et al., 2015), in particular ${ }^{14} \mathrm{C}$ ka time-slice reconstructions for the period $25-10{ }^{14} \mathrm{C}$ ka (Fig. 2). Many ice models are based on relative sea-level data (Coulson et al., 2021), whereas other ice models derive from space geodesy data (e.g., Peltier, 2004; Peltier et al., 2015; Vestøl et al., 2019).

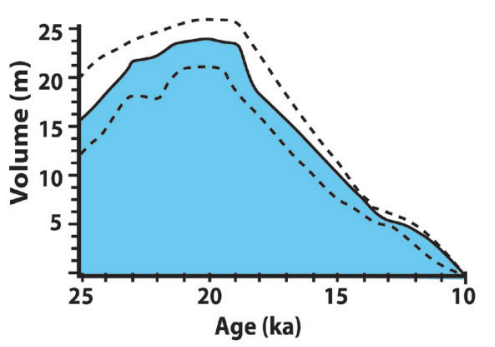

Fig. 2. Ice volume of the Fennoscandian ice sheet expressed in sea-level equivalents. The most credible maximum and minimum volumes are shown by stippled lines (modified from Hughes et al., 2015). Ages in ${ }^{14} \mathrm{C} \mathrm{ka}$. The global mean sea level (Carlson \& Clark, 2012) increased nearly uniformly after the Last Glacial Maximum, exhibiting a typical rate of increase to $10 \mathrm{~m} \mathrm{ka}^{-1}$ during the 16-6 ka period.

The reconstruction in terms of approximate sea-level equivalents highlights the first-order spatial and temporal variation in ice-sheet retreat, and the contribution of sea-level equivalents ranges from 5-0 m during the 12-9 ka early Holocene period (Carlson \& Clark, 2012). The global mean sea-level increased nearly uniformly after the Last Glacial Maximum, exhibiting a typical rate increase to $\sim 10$ $\mathrm{m} \mathrm{ka}{ }^{-1}$ during the 16-6 ka period. It passed $\sim-50 \mathrm{~m}$ at $\sim 11.6 \mathrm{ka}$ and $\sim-15 \mathrm{~m}$ at $\sim 8.2 \mathrm{ka}$, approaching recent levels at $\sim 7 \mathrm{ka}$, responding to the retreating and diminishing Northern Hemisphere ice sheets. The contribution of sea-level equivalents ranges from -5 $\mathrm{m}$ during the $\sim 12-9$ ka early Holocene period. Subsequently, the rate decreased, yielding only a 3-5 $\mathrm{m}$ rise towards the present as major meltwater input ceased (Bard et al., 1996; Fleming et al., 1998).

Some large earthquakes might cause increased submarine and onshore landslide frequencies, creating new surface water pathways, damming and flooding (Huang \& Fan, 2013; Broeckx et al.,

${ }^{1}$ Unless noted, we use calendar year before present BP and moment magnitude, $M_{w}$. Conversion from ${ }^{14} \mathrm{C} y r$ by the procedure at http://calib.org/calib/, and from varve years according to Bellwald et al. (2018a). 
2020; X. Fan et al., 2020). Thus, the impact of regional transient meltwater events on lithospheric stress change, resulting from sudden drainage of large water and ice reservoirs, needs attention. Such superlakemegafloods (Baker, 2002; Clarke et al., 2003) may yield rapid sea-level rises (Gregoire et al., 2012) by collapse of ice saddles or break-up of sediment barriers in cases triggered by earthquakes. In fact, huge flood events would leave a global mean sea-level imprint with magnitudes that reflect the discharge volume (Kendall et al., 2008), with potentials for inducing and/or amplifying short climatic events.

\section{Paleoearthquakes}

Early and mid-Holocene earthquakes are paleoearthquakes, i.e., pre-historic, considered to have occurred prior to written accounts (McCalpin \& Nelson, 1996). Despite the present global low-level seismicity in stable continental regions (SCRs; Johnston \& Kanter, 1990), early Holocene paleoearthquakes, some of which may have had large magnitudes (Schwartz, 1987; Crone et al., 1997; Grant, 2002), occur both in rifted and non-rifted plate interiors (Schulte \& Mooney, 2005). Moreover, in many high-latitude SCRs the Holocene, and in part the current crustal strain-rate field, is still dominated by deglaciation (Muir Wood, 2000).

Mapping of paleoearthquakes is mainly based on geological, societal and environmental features, in particular geomorphological mapping and trenching of suspected faults (Table 1). The recognition of fault-graded sedimentary sequences displaying deformation structures produced by seismic shaking, i.e., seismites, may help to date the seismic events. Moreover, archaeology provides paleoearthquake information, and paleoevents appear also in geomythology.

Table 1. Methods and procedures for dating paleoearthquakes. MTD: mass transport deposits. The criteria for assigning a postglacial age to some of the events are summarised by Mikko et al. (2015).

\begin{tabular}{|c|c|c|c|}
\hline Method & Procedure & Datable - D & Reference \\
\hline Environmental & & & McCalpin \& Nelson, 1996 \\
\hline Geomorphology & $\begin{array}{l}\text { Mapping - landslides and } \\
\text { landforms vs fault scarps }\end{array}$ & $\mathrm{D}$ & He et al., 2016. \\
\hline Seismites & Trenching & $\mathrm{D}$ & Shenghua et al., 2014. \\
\hline \multicolumn{4}{|l|}{ Societal } \\
\hline Archaeology & Dating of societal impact & $D$ - in cases & Nur, 2002. \\
\hline Geomythology & « « & D - uncertain & Piccardi \& Masse, 2007. \\
\hline Geological & & & McCalpin \& Nelson, 1996. \\
\hline Alluvial river deposits & Mapping & $\mathrm{D}$ & Schwartz, 1987. \\
\hline Landslides & Mapping & $\mathrm{D}$ & Jibson, 1996. \\
\hline Marine sediments & MTDs & $\mathrm{D}$ & $\begin{array}{l}\text { Gràcia et al., 2017; De Batist et } \\
\text { al., 2017; Bellwald et al., 2018a. }\end{array}$ \\
\hline Lake sedimets & MTDs & $\mathrm{D}$ & Strasser et al., 2013. \\
\hline Pockmarks & Mapping & $\mathrm{D}$ & $\begin{array}{l}\text { Reuch et al., 2016; } \\
\text { Mazzini et al., } 2017\end{array}$ \\
\hline Rock avalanches & Mapping & D - in cases & Valagussa et al., 2019. \\
\hline
\end{tabular}


Earthquakes may have left datable alluvial river deposits and landslides, whereas subaquatic paleoseismology records Holocene paleoearthquakes in marine and lacustrine sediments by dating of mass-transport deposits (MTDs) to reconstruct marine and lake seismicity. The method is particularly applicable to high-latitude fjord deposits (Bellwald et al., 2016). In fact, the repetitive turbidite deposits in the eastern Mediterranean reveal a direct link between earthquakes and mass wasting in the period 6.0-10.2 ka, at 100-700-year recurrence intervals (Polonia et al., 2015). However, parameters such as date, magnitude, fault slip rate and recurrence interval commonly arrive from circumstantial evidence (Swafford \& Stein, 2007), and the methods do not apply to blind faults. In fact, it has been assessed that seismogenic blind thrust faults may have accommodated early Holocene magnitude 6.5-7 earthquakes in the vicinity of the Norwegian continental margin without surface rupturing (Bungum et al., 2005; 2009).

\section{The Greater Lapland Fault Province}

As noted by Bungum et al. (2010), more than a hundred years ago Kolderup (1913) suggested that uplift of the Scandinavian land mass is the most likely reason for contemporary earthquakes, while Nansen (1922) also addressed the topic. Moreover, Båth (1953) declared that "it is almost unanimous agreement between earlier investigators of Fennoscandian earthquakes that they are due to stresses produced by the differential uplift of the land after the last ice age". While our perspectives on this may differ today, the above quotes show that early investigators were aware of the importance of the Fennoscandian uplift.

Since the Lapland faults were documented (Kujansuu, 1964; Lagerbäck 1979; Olesen 1988), the presumed associated seismicity has been discussed in a number of studies (e.g., Wahlström \& Kulhánek, 1983; Wahlström, 1993; Arvidsson, 1996; Lagerbäck \& Sundh, 2008; Lund et al., 2009; Kukkonen et al., 2010; Abdi et al., 2015). Fig. 1, which shows significant postglacial rupturing in the LFP as well as some faulting beyond LFP, is mainly based on the LFP map of Olesen et al. (in press), expanded towards the west and south to include areas of potential secondary phenomena.

\section{Historical and present-day seismicity}

Both the LFP and most of the Fennoscandian SCR have historically exhibited limited seismic activity (Fig. 3), including small, sometimes clustered, events along the Norwegian coast and along the continental margins (Bungum \& Selnes, 1988; Byrkjeland et al., 2000; Fjeldskaar et al., 2000; Bungum et al., 2005; Olesen et al., in press). The LFP yields earthquakes of M up to 3-4.5 (Slunga, 1991; Arvidsson, 1996; Bungum \& Lindholm, 1996; Juhlin et al., 2010; Olesen et al., 2013), with microseismicity correlating spatially with mapped fault scarps (Lindblom et al., 2015). In fact, both the Pärvie Fault and the Stuoragurra Fault Complex (SFC) are still active in the sense that they exhibit microseismicity at present (Lindblom et al., 2015; Olesen et al., in press). However, since the crustal stress regime in this region has changed considerably since the postglacial period, we interpret the present seismicity essentially as a response to the present-day stress regime within weakness zones defined by the pre-existing LFP structures (Bungum \& Lindholm, 1996). Similarly, the present level of hazard on these faults is far below what it was during the deglaciation (Bungum et al., 2005; Lindholm, 2019).

On a global scale, the seismicity of Norway (Fig. 3) is low-to-intermediate, even though it is among the highest in northern Europe (Olesen et al., 2013). The largest earthquakes in recent times occurred on 


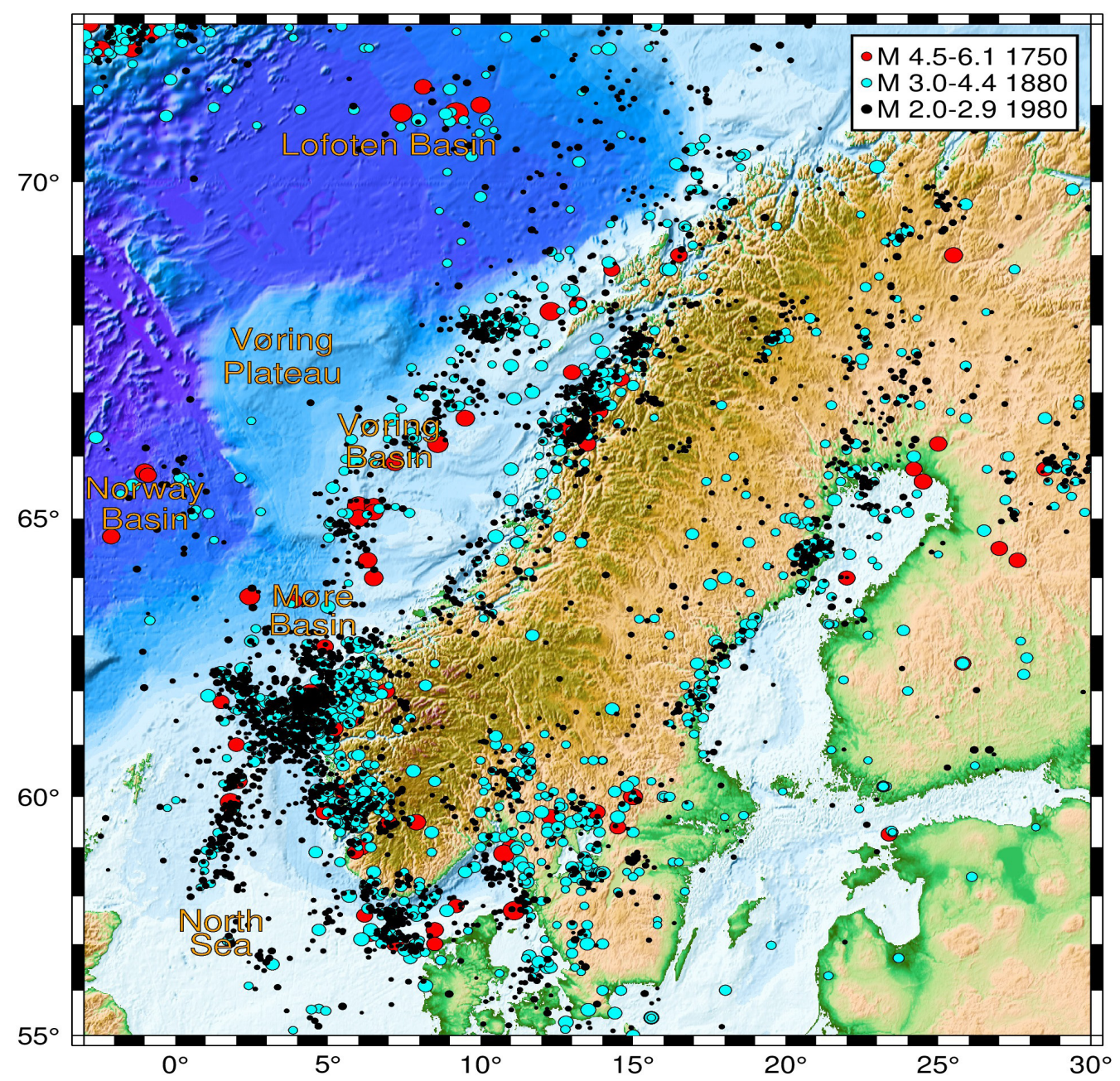

Fig. 3. Seismicity of Fennoscandia plotted with topographic and bathymetric reliefs (see Fig. 1 for GLFP faults). The earthquake catalogue used is FENCAT (2020) described by Ahjos \& Uski (1992), providing data up to and including 2014. Some of the larger earthquakes in and offshore Norway have been corrected in both location and magnitude (Conrad Lindholm, pers. comm. 2019). Three time periods with different colour coding are plotted: M 4.5-6.1 since 1750 (red, starting with the 1759 Skagerrak earthquake (Table 4)), M 3.0-4.4 since 1880 (cyan), and M 2.0-2.9 since 1980 (black). Symbol size proportional to magnitude.

Svalbard in 2008, M 6.0 (Pirli et al., 2010); in the Rana region in 1819, M $5.8^{2}$ (Muir Wood, 1988, 1989; Bungum \& Olesen, 2005); in the Vøring Basin in 1866, M 5.7; in the outer Oslofjord in 1904, M 5.4 (Bungum et al., 2009); and in the Viking Graben in 1927, M 5.3 (Bungum et al., 2003). The most recent $M>5$ earthquakes include an M 5.3 event in the Vøring Basin in 1988 and an M 5.2 event in the northeastern North Sea in 1989 (Hansen et al., 1989).

The seismicity of Fennoscandia is strictly intraplate, also along the passive continental margin. Even so, however, an E-W profile from oceanic crust through the Caledonides to the Baltic Shield covers a region subject to strain rates with variations of several orders of magnitude (Bungum et al., 2005; Kierulf et al., 2014; Keiding et al., 2015) and large variations in tectonic conditions. The main control on the seismicity in this region appears to be the continental margin proper, with large lateral variations in structural composition within it. Moreover, as seen in Fig. 3, some of the large sedimentary basins (notably the

\footnotetext{
${ }^{2}$ While the magnitude reassessment of 5.8 for the 1819 earthquake by Bungum \& Olesen (2005) was based on felt areas, Mäntyniemi et al. (2020) in a subsequent reassessment found M 5.9, based on a different approach with 29 individual intensity observation points. The magnitude uncertainty in all such estimates is at least \pm 0.2, however.
} 
Lofoten Basin and the Norway Basin) also have a clear seismicity signature, as discussed by Byrkjeland et al. (2000). In the Nordland region there is also a parallel, shallow seismic lineation along the coast, representing mostly extensional stress release. Other seismic areas are in the failed graben structures in the North Sea and in the Oslo Rift zone (Bungum et al., 2000, 2009).

This pattern of seismicity is largely consistent with the conclusions from global SCR studies (Johnston et al., 1994; Schulte \& Mooney, 2005), finding that rifted passive margins and failed rifts are the two main types of host structures responsible for the largest earthquakes. Globally, there are of the order of 20 SCR earthquakes above magnitude 7 known to us (Bungum et al., 2005). Recent studies from Australia (Leonard \& Clark, 2011; Clark et al., 2012) indicate that this number is likely to be steadily increasing. Even though the number and magnitudes of the largest SCR earthquakes have been challenged by Schulte \& Mooney (2005), it should be kept in mind that the recurrence times at any given SCR location could easily be thousands of years, in contrast to decades or centuries at plate margins.

\section{The Lapland Fault Province}

The early Holocene LFP deformation is evident by some very large earthquakes reaching magnitudes 7-8.2, dated by seismites in trench exposures to 9-8 ka, and supported by numerous landslides developed in glacial tills (Lagerbäck \& Sundh, 2008). At least 14 postglacial LFP reverse fault scarps, trending SW-NE, mostly SE dipping and up to $160 \mathrm{~km}$ long and $30 \mathrm{~m}$ high, have been identified (Fig. 1). The largest rupture, the Pärvie Fault, has been associated with an earthquake of magnitude between 7.8 and 8.2 (Muir Wood, 1989; Arvidsson, 1996; Bungum \& Lindholm, 1996; Johnston, 1996; Lindblom et al., 2015), all based on the assumption of a whole-scarp rupture.

Some of the LFP earthquakes may have had larger magnitude than most SCR earthquakes elsewhere, and their discovery consequently invoked characterisations like extraordinary (Muir Wood, 1989), enigmatic episodes (Lagerbäck \& Sundh, 2008), unique on Earth (Kukkonen et al., 2010) and unique globally (Abdi et al., 2015). Importantly, Lagerbäck \& Sundh (2008) found no evidence of faulting during previous deglaciations and therefore inferred a different stress regime during the older glacial periods. Smith et al. (in press) conclude, however, that some of the high-relief scarps existed prior to deglaciation, calling for a reassessment of the single-rupture hypothesis. Moreover, fault stability analysis supports a change from stable to unstable conditions at the end of the glaciation (Wu et al., 1999; Lund et al., 2009); whereas Abdi et al. (2015) inferred that the present stress regime is different from that during the formation of the LFP paleofaults and associated landslides. Nonetheless, the absence of older faults during previous glaciations is indeed enigmatic (Eldholm \& Bungum, in prep.).

Muir Wood (1989) considered all postglacial faults as listric. In fact, seismic images of the Pärvie Fault show that it is moderately to steeply dipping to at least $2-3 \mathrm{~km}$ depth, perhaps to $>6 \mathrm{~km}$, constituting an apparent flower structure merging at depth (Juhlin et al., 2010). Coeval faults exist in N Finland, where the Suasselkä Fault extends to $\sim 3 \mathrm{~km}$ depth (Abdi et al., 2015), and a greatly deformed but separate fault system, the Sjaunja Scarp, lies $\sim 50 \mathrm{~km}$ east of the Pärvie Fault (Mikko et al., 2015). Drilling confirms postglacial reactivation of the Palojärvi Fault (Sutinen et al., 2014), whereas two E-W and NW-SE trending features are probably younger. Moreover, Sutinen et al. (2018) suggest a number of sub- and postglacial earthquake-induced landforms in the Kuusamo area in NE Finnish Lapland (Fig. 1). If related to fault scarps, many of the abundant landslides and landforms might be caused by old faults reactivated during the early Holocene (Lagerbäck \& Sundh, 2008; Mörner, 2009; Lindqvist, 2010; Berglund \& Dahlström, 2015; Mikko et al., 2015; Palmu et al., 2015; Mangerud et al., 2018; Ojala et al., 2018a). 
In the Swedish LFP, most fault scarps are located in Precambrian granitic bedrock, trending along old Proterozoic structures and commonly terminating against mafic rocks within the bedrock (Lagerbäck, 1979; Lagerbäck \& Sundh, 2008; Juhlin et al., 2010), thereby acting as local stress concentrators (Talwani, 2017).

Many faults that are associated with landslides and related features are commonly termed end-glacial, implying fault movement at, or near, the time when the last ice receded (Juhlin et al., 2010). Although some deformation features are ambiguous in nature and without reliable dating, many faults might reflect a major neotectonic pulse, comprising several M 7-8 earthquakes (Bungum \& Lindholm, 1996), apparently in response to deglaciation, rupturing as single events through the entire crust (Arvidsson, 1996). Lagerbäck \& Sundh (2008) infer that the rupturing occurred shortly after the local deglaciation. The LFP became ice-free during 10.5-10.0 ka; thus, they dated the faulting to 10.0-9.5 ka (Table 2).

Table 2. Summary of early Holocene earthquakes in GLFP (Fig. 1), or features that might be generated by earthquakes, based on information in the literature cited in the text. Thus, it includes information from both fault scarps and landforms. Note that trenching might include datable seismites.

\begin{tabular}{|c|c|c|c|}
\hline Region & Observations / Analyses & Dates (ka) & Magnitude \\
\hline \multirow{2}{*}{ GLFP - this paper } & Various. Mostly landslides & $11.5-9.0$ cluster $10-9$ & \\
\hline & and landforms & $\sim 8.0-5.5$ & $7.5-6.7$ \\
\hline \multirow[t]{2}{*}{ LFP } & Trenching & $10.0-9.5$ & $7-8.2$ \\
\hline & LFP ice-free & $10.5-10.0$ & \\
\hline \multirow[t]{2}{*}{ Sweden (Mörner) } & Various, mainly varve analysis & $\sim 11.0-9.0$ & $>8$ \\
\hline & & Late and mid-Holocene & 6.0 events $>8$ \\
\hline LFP & Fault stability analysis & $13-9, \max 11-9$ & \\
\hline Lake Vättern Graben & $\begin{array}{l}\text { 80-km-fault-system in datable } \\
\text { sediments, seismic, coring }\end{array}$ & $\sim 11.5$ & Up to 7.5 \\
\hline Bollnäs Fault & Mapping & 10.18 & $5.5,6-6.5$ \\
\hline $\begin{array}{l}\text { Jämtland, } \\
\text { central Sweden }\end{array}$ & LIDAR, elevation models & & $\sim 5.7$ \\
\hline Finland & Lake sediments & $12-10,5-7,1.5-3$ & $\sim 7$ or higher \\
\hline Finnish LFP & Landslides & $11-9,6-5$ & $\sim 6.7-7.5$ \\
\hline Central-S Finland & Ruptures & $10.7-10.2$ & 5.1-7.7 \\
\hline Olkiluoto area & & $\sim 7.4$ & \\
\hline $\begin{array}{l}\text { Troll pockmark field, } \\
\text { N Sea }\end{array}$ & U-Th dates & $9.59 \pm 1.38$ & \\
\hline W Norway & Rock avalanches & $12-10$ & \\
\hline Storegga Slide & Submarine mega-slide & 8.1 & \\
\hline Stuoragurra Fault & Geophysics, trenching, GPR & $9-11,5-6,1-3$ & $6.4-8.0$ \\
\hline \multicolumn{4}{|l|}{ Complex. N Norway } \\
\hline \multirow[t]{2}{*}{ Norw. fjords and lakes } & MTDs & $11.0-9.7$ & \\
\hline & & $8.3-7.7$ & \\
\hline \multirow[t]{2}{*}{ S Norway $61.1^{\circ} \mathrm{N}$} & Landslide & Max. 6.36 & Strong \\
\hline & Region ice-free & $10.5 \mathrm{ka}$ & \\
\hline
\end{tabular}




\section{Expanding the Lapland Fault Province}

We now examine the evidence for postglacial seismic activity beyond LFP.

Mörner (2005, 2009) proposed relatively frequent post- and late-glacial paleoseismicity in Sweden, including the LFP. His prolific work, based mostly on varve analysis, reflects a significant regional crustal response to the last deglaciation, with 54 paleoseismic events all over Sweden. Some of these are $M>8$, of which 50\% were claimed to occur during 11.8-9.7 ka (Mörner, 2009), i.e., during the time of maximum rates of glacial isostatic uplift. He also reported a major tsunamigenic event at $6.1 \mathrm{ka}$, as well as several relatively large-magnitude events during Middle and Late-Holocene. However, this contention of Holocene faulting in central and southern Sweden has created a lively, sometimes acrimonious, discourse (e.g., Smith et al., 2014; Malehmir et al., 2016). The arguments, in part summarised by Lund et al. (2009), Lagerbäck \& Sundh (2008) and Mikko et al. (2015), provide little conclusive evidence of late- or postglacial faulting south of $\sim 64-66^{\circ} \mathrm{N}$, and a particularly strong and detailed rebuttal is provided by Lund et al. (2017). A particular problem with Mörner's claims, derived from observations in varved sediments, is that a corresponding, coeval fault rupture in bedrock is not found, despite proposed magnitudes which should have given rise to bedrock dislocations over large distances, too large to be erased through erosional processes.

Even so, faulting south of the LFP is by no means dismissed, but if it occurred it would have had to be less pronounced than farther north. Why the earlier documented postglacial faults were limited to the Lapland region has never been fully understood or justified. Nonetheless, recent well-documented structures in central Sweden (Berglund \& Dahlström, 2015; Mikko et al., 2015), and numerical modelling by Wu et al. (1999) and Lund et al. (2009), may well reignite this discussion. In addition to bedrock features mapped from aerial photographs, LIDAR mapping (Mikko et al., 2015) has revealed 234 scarp segments increasing the total fault lengths by only $2.2 \mathrm{~km}$ in the LFP and in central Sweden. However, no faults were identified in southern Sweden, arguing against Mörner (2005).

Nonetheless, recent geophysical mapping (Jakobsson et al., 2014) and coring (Swärd et al., 2015) have revealed neotectonic movements along the SSW-NNE-trending, Precambrian, Lake Vättern Graben in southern Sweden dated to $11.5 \mathrm{ka}$, where up to $13 \mathrm{~m}$ of vertical displacement is inferred along a $>80$ km-long fault system (Fig. 1). If the displacement is from one tectonic event, Jakobsson et al. (2014) suggested it may have generated an up to M 7.5 earthquake, i.e., comparable to the larger LFP events, thus supporting the contention of Mörner (1985) of earthquake-triggered landslides and turbidites in the northernmost lake. On the other hand, LIDAR mapping shows no postglacial faults beyond Lake Vättern, and Mikko et al. (2015) claim that the offset exists only beneath the lake. Paleoseismic activity $\sim 400 \mathrm{~km}$ beyond the LFP is also consistent with a prominent $12 \mathrm{~km}$-long N-S trending scarp 250 km north of Stockholm, the Bollnäs Fault. In Fig. 1 we have added a $\sim 4$ km-long southern extension of the fault as introduced by Malehmir et al. (2016). The rupture may have triggered a $M>5.5$ earthquake shortly before 10.18 ka (Smith et al., 2014), or an event of magnitude 6-6.5 caused by reverse faulting predetermined by an existing deformation zone in basement rocks (Malehmir et al., 2016). Moreover, several fault scarps in Jämtland, central Sweden, have been mapped by LIDAR and digital elevation models and interpreted to reflect an area of postglacial deformation dated to 10 ka (Berglund \& Dahlström, 2015). Note that the dating is from morphology and by comparison with similar features elsewhere in Sweden, thus not by independent methods. The scarps are 0.4 to $6 \mathrm{~km}$ long and 2-8 m high (Fig. 1), and Berglund \& Dahlström (2015) estimated that the faulting may have resulted in an earthquake of magnitude $\sim 7$.

The fault system segmentation observed in Sweden and Norway is also characteristic for Finnish Lapland (Fig. 1; Posiva, 2019). Landslides in western Finnish Lapland (Ojala et al., 2018a) reveal three periods of slope instability dated to 11-9 ka, 6-5 ka and 3-1 ka, whereas analysis of ruptures and landforms in 
N Finland date the seismic activity to $\sim 11.3 \mathrm{ka}$, yielding earthquakes in the magnitude range of 6.7-7.5 (Ojala et al., 2017a, b). On the other hand, deformation of varved sediments in central and southern Finland, beyond the LFP, reveal a later mid-Holocene pulse of seismic activity of magnitudes 5.1-7.7, dated as $\sim 7.4$ ka, i.e., 3.5 ka after regional deglaciation (Ojala et al., 2018b; Posiva 2019; Figs 1, 4). However, the links between earthquakes and disturbed varved sediments are by no means simple.

A comprehensive study of lake sediments adjacent to Holocene ruptures in northern Finland by Ojala et al. (2019) reveal temporal clusters of paleoseismicity. The oldest, during 12.0-10.0 ka, is related to deglaciation, followed by mid-Holocene events in the period 7.0-5.0 ka, and by Late Holocene events dated to $3.0-2.5 \mathrm{ka}$ (Fig 4). They also propose that the Finnish ruptures propagated from SW to NE, and that the deglaciation events attained magnitudes of 7 or more in the southwestern part of the GLFP. Rupture features beyond the LFP have also been reported off the Olkiluoto region ("Ol" in Fig. 1) in the Baltic Sea, dated to 10.7-10.2 ka (Kotilainen \& Hutri, 2004; Hutri \& Kotilainen 2007; Hutri et al., 2007; Palmu et al., 2015), and in the Lauhanvuory fault system ("Lau" in Fig. 1). The offshore features in the Olkiluoto area show normal faults, apparent gas or groundwater seepage, submarine slides and debris flows. Coeval rupturing features are also observed in Russia (Kukkonen et al., 2010; Nikolaeva et al., in press) and in Germany (Brandes et al., 2019).

The known neotectonic features in Norway have been reviewed and graded by Olesen et al. (2004) using the criteria of Muir Wood (1993) and Fenton (1994). Both the (weakly) active Stuoragurra Fault Complex in LFP (Olesen, 1988), and the Nordmannvikdalen Fault in N Norway (Dehls et al., 2000; Fig. 1) were considered almost certainly postglacial, rupturing as single-rupture events at the end of the deglaciation $\sim 9.3$ ka or shortly thereafter. Subsequently, Olesen et al. (2013) confirmed their nature, whereas they reclassified all previously apparent neotectonic features as nontectonic and noted that the Stuoragurra Fault Complex is still active at depth. However, Redfield \& Hermanns (2016) queried the neotectonic nature of the Nordmannvikdalen Fault, whereas trenching and radar profiling by Olsen et al. (2018) supported the neotectonic interpretation.

Recently, Olesen et al. (in press) have shown that the Stuoragurra Fault Complex (SFC) constitutes three separate fault sets along a $\sim 4-5 \mathrm{~km}$-wide regional shear zone within the Fennoscandian Shield, dipping $30-75^{\circ}$ to the southeast to a depth of $\sim 3 \mathrm{~km}$. An integrated geophysical survey, including seismic profiling and magnetotelluric inversion, has confirmed the configuration of the SFC (Mrope et al., 2019;

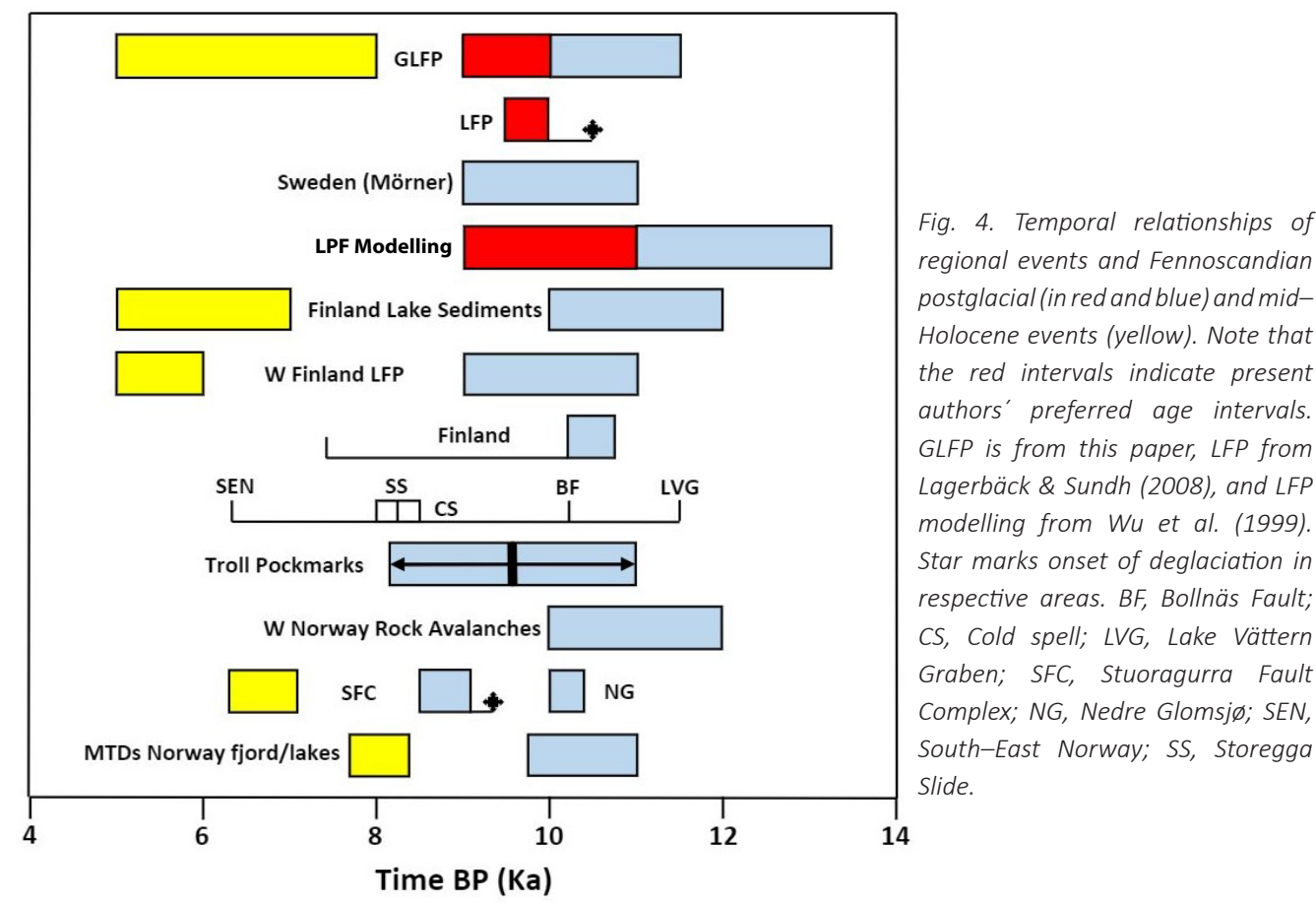

10 of 42 
Olesen et al., in press); showing that the $90-\mathrm{km}$-long reverse fault is separated by gaps without any apparent faulting. Trenching in deformed peat and gyttja layers yields deformation ages of 9-11, 5-6 and 1-3 ka, thereby separating the SFC into three distinct fault sets formed at different times. Such events may have yielded M 6.4-8.0 earthquakes (Olsen et al., 2020; Olesen et al., in press). We note that such multiple dates for seismic events have also been reported in N Finland (Mattila et al., 2019; Ojala et al., 2019).

Mangerud et al. (2018) proposed an earthquake-triggered landslide near the Norwegian town of Lillehammer $\left(\sim 61.0^{\circ} \mathrm{N}\right.$, Figs. 1 \& 4). Here, 10.5 ka-old lacustrine sediments covered by $\sim 0.5 \mathrm{~m}$ of peat capping a $\sim 2 \mathrm{~m}$-thick, coarse-grained, debris flow were dated as at most $6.36 \mathrm{ka}$; i.e., $\sim 4.0$ ka since the glaciers retracted from the region. By analogy with results in Finland they proposed that the debris-flow sequence originated from a strong earthquake, but also noted that mass movement on the modest slope of $2.6-4^{\circ}$ is enigmatic. Abundant flooding events occurred during deglaciation (Hansen et al., 2020; Regnéll et al., 2020) and may have left debris-flow deposits, and we add that the movements occurred in a wooded region, normally not conducive to liquefaction effects from an earthquake. However, the fact that landslides may occur on very low-angle slopes, $<2^{\circ}$, has been documented repeatedly, such as from the M 7.52018 Palu earthquake in Indonesia (Bradley et al., 2019; Watkinson \& Hall, 2019), albeit in a region having undergone anthropogenic environmental change. Moreover, large submarine landslides may occur on slopes $<2^{\circ}$ (Urlaub et al., 2015). In fact, many of the numerous inferred earthquake-triggered landslides in the GLFP exhibit very low-angle slopes, commonly associated with liquefaction.

We suggest an age range of 11.5-9.0 ka for the GLFP with a cluster at 10-9 ka that we consider postglacial events, i.e., occurring during the time when the GLFP region became free of ice (Fig. 4; Table 2). The postglacial faults in Fennoscandia initiated numerous landslides (Lagerbäck \& Sundh, 2008; Sutinen et al., 2014). However, there is also increasing information pertaining to somewhat younger events, mainly from sliding, flooding and landforms, possibly triggered by GLFP/LFP earthquakes. Thus, we have included in Table 2 and in Fig. 4 a period of apparent events during 8.0-5.5 ka, which we denote as mid-Holocene events, i.e., occurring when the epicentral region was entirely ice-free $~ 3-4$ ka after the region was deglaciated. In addition, there are indications of more recent activity along the SFC and in land and lake sediments in the Olkiluoto region, Finland (see Table 2, with dates), an issue that we will return to later. In fact, about 60 landslides appear on LIDAR data along the segmented SFC (Olesen et al., in press), and it appears that the segmented and non-single ruptures in the SFC is characteristic for the majority of the GLFP fault systems in general.

Lately, the term postglacial faults (PGFs) has been introduced, encompassing all structural deformation since deglaciation (Posiva, 2019). Here, we apply the terms, postglacial, midHolocene and Late-Holocene events to encompass the majority of event ages. However, we stress that we consider the younger periods to be far more uncertain than the postglacial fault-based dates in Fig. 4. An apparent time-regressive trend is apparent in the data, with younger ages northward as the ice sheets retracted. The somewhat uncertain date range of the younger, mid-Holocene, apparent event cluster primarily arrives from mapping of landslides and landforms. Nonetheless, we still suggest a glacial origin either by short-lived climatic events inducing glacier advances and retreats, or by relatively large local and/or regional glaciers left behind. For Late-Holocene events, not discussed here, we refer to Olesen et al. (in press). 


\section{Potential secondary phenomena}

Accepting that the GLFP seismicity during deglaciation may have initiated secondary phenomena, we now address five categories of such phenomena, which may be interrelated (Table 3). Initially, we address some historical events as examples of how Fennoscandian earthquakes have impacted the environment. If sediment and rock formations are unstable, earthquakes may initiate downward mass movements and/or structural deformation both offshore and onshore. Both in the GLFP and along the Norwegian margin, the deformation relates to rejuvenation and inheritance of pre-existing structural features (e.g., Talwani \& Eldholm, 1972; Eide et al., 1997; Lagerbäck \& Sundh, 2008; Henstra et al., 2019). In turn, Glacially Induced Faulting (GIF) may yield earthquakes that can induce mass wasting and tsunamis whose magnitudes mainly relate to water depth, slide volume and the nature of slide fragmentation (Tappin, 2010). In submarine settings, the climate by way of deglaciation controls the type of mass wasted sediment and its rate of delivery, inducing deposition of mechanically weak layers, and allowing conditions for fluid and gas overpressure.

Table 3. Secondary earthquake-caused phenomena observed on the Norwegian continental margins and in adjacent areas. $T, R$ and $L$ refer to the epicentral distances: Teleseismic or far-field $(T>\sim 2000 \mathrm{~km})$, regional $(R=\sim 800-\sim 2000 \mathrm{~km})$ and local ( L < 800 km) seismic events (Havskov \& Ottemöller, 2010).

\begin{tabular}{|c|c|c|c|}
\hline Phenomena & $\begin{array}{l}\text { Earth- } \\
\text { quake }\end{array}$ & Mechanism & Potential consequence \\
\hline Unstable continental margin & $\mathrm{T}, \mathrm{R}, \mathrm{L}$ & Mass wasting & $\begin{array}{l}\text { Megaslide, slide, seiche, } \\
\text { tsunami }\end{array}$ \\
\hline Unstable lake and fjord walls & $\mathrm{R}, \mathrm{L}$ & Mass wasting (MTDs) & Fjord seiches, local tsunami \\
\hline Rock-sediment-soil avalanche & $R, L$ & Unstable rock surface & Regional to local tsunami \\
\hline $\begin{array}{l}\text { Ice and sediment barrier } \\
\text { breakup }\end{array}$ & $\mathrm{T}, \mathrm{R}, \mathrm{L}$ & $\begin{array}{l}\text { Changing drainage } \\
\text { pattern }\end{array}$ & Flooding, new current systems \\
\hline Gas hydrate & $\mathrm{T}, \mathrm{R}, \mathrm{L}$ & $\begin{array}{l}\text { Submarine hydrate } \\
\text { release }\end{array}$ & Pockmarks, climate gases \\
\hline
\end{tabular}

\section{Some historical events}

Even at large epicentral distances, earthquakes might inflict societal damages, initiate mass movements and tsunami activity on Fennoscandian continental margins and coasts, causing seiches in fjords and lakes and inducing mass-wasting processes datable by the occurrence of mass-transport deposits (MTDs). We document such effects in Table 4 by some examples of large teleseismic and regional earthquakes that have affected Fennoscandia, and particularly Norway. We also include an intriguing observation most likely from a more recent local mass-wasting event in Nordfjord, W Norway. The purpose is to document that GLFP events may indeed have had the power and epicentral distances to induce secondary features, on the adjacent continent, continental margin, and in lakes, fjords and inland seas.

The well-known consequences of the relatively large historical 1819 Helgeland and 1759 Kattegat earthquakes document devastation at both local and regional distances, as well as water mass oscillations, or seiches, in fjords and lakes (Table 4). However, seiches are also caused by large teleseismic earthquakes (Tables 3-4), being standing waves in basins and channels with an eigenperiod similar to the period of the ground movement induced by the earthquake (Kvale 1955; McGarr \& Vorhis, 1968). The natural seiche period is $T^{\sim} 2 \mathrm{~W} /(\mathrm{gD})^{1 / 2}$, where $\mathrm{W}$ and $\mathrm{D}$ are the average basin width and depth, respectively, and $g$ is the gravity field strength (McGarr, 1965). Thus, teleseismic events might generate seiches as well as mass wasting. Notably, Johnson et al. (2017) have shown that 
Table 4. Fennoscandian seiches reported from teleseismic or far-field $(T>2000 \mathrm{~km})$, regional $(R=800-2000 \mathrm{~km})$ and local $(\mathrm{L}<800 \mathrm{~km})$ seismic events (Fig. 5). Historical events based on Muir Wood \& Woo (1987). The Nordfjord fjord-seiche event has uncertain timing, and it is questionable whether it is a seiche proper or, more likely, initiated by a local submarine slide reaching its instability level, rather than an earthquake. MMI: Modified Mercalli Intensity.

\begin{tabular}{|c|c|c|c|c|}
\hline Earthquake & M/MMI & Fennoscandian seiches & Comment & Reference \\
\hline $\begin{array}{l}1.11 .1755 \\
\text { Lisbon }\end{array}$ & $7.2-8.2$ & $\begin{array}{l}\text { Lakes Norway and Sweden. } \\
\text { Norwegian fjords }\end{array}$ & T-Widespread damage & $\begin{array}{l}\text { McGarr \& Vorhis, 1968; } \\
\text { Kvale, 1955; Jørstad, } \\
\text { 1968; Fonseca, } 2020\end{array}$ \\
\hline $\begin{array}{l}22.12 .1759 \\
\text { Kattegat } \\
57.7 \mathrm{~N}, 11.1 \mathrm{E}\end{array}$ & $\begin{array}{l}\text { VII, } M_{S} \\
5.4-5.6\end{array}$ & $\begin{array}{l}\text { Elsinor, Denmark: } \\
\text { Agitated sea }\end{array}$ & $\begin{array}{l}\mathrm{R} / \mathrm{L} \text { - felt } 600 \mathrm{~km} \text {. Minor } \\
\text { damage to buildings. }\end{array}$ & Muir Wood, 1988 \\
\hline $\begin{array}{l}\text { 31.8.1819 } \\
\text { Helgeland (Lurøy) } \\
66.4^{\circ} \mathrm{N}, 13.1^{\circ} \mathrm{E}\end{array}$ & $\begin{array}{l}\text { VIII, } \\
\mathrm{M}_{\mathrm{S}} \\
5.8-6.2\end{array}$ & $\begin{array}{l}\text { Disturbances in fjords } \\
\text { and sea. Standing waves } \\
\text { in Ranafjord, Norway }\end{array}$ & $\begin{array}{l}\mathrm{R} / \mathrm{L} \text { - felt } 800 \mathrm{~km} \\
\text { Extensive rock fall and } \\
\text { liquefaction features. }\end{array}$ & $\begin{array}{l}\text { Muir Wood, 1988; Furseth, } \\
\text { 2012; Olesen \& Lindholm, } 2019 .\end{array}$ \\
\hline $\begin{array}{l}\text { 16.12.1920 } \\
\text { Kansu (China) }\end{array}$ & 8.5 & $\begin{array}{l}\text { Osterfiord, Nordfiord } \\
\text { and two lakes in W Norway, } \\
\text { possibly elsewhere. }\end{array}$ & $\mathrm{T}$ & Kvale, 1955; Jørstad, 1968 \\
\hline $\begin{array}{l}\text { 15.8.1950 } \\
\text { Assam }\end{array}$ & 8.6 & $\begin{array}{l}\text { At least } 37 \text { lake } \\
\text { and fjord localities. }\end{array}$ & $\mathrm{T}$ & \\
\hline $\begin{array}{l}\text { 27.3.1964 } \\
\text { Alaska }\end{array}$ & 9.2 & Osterfjord, Sognefjord. & $\mathrm{T}$ & $\begin{array}{l}\text { McGarr 1965; McGarr \& Vorhis, } \\
\text { 1968; Bondevik et al., } 2015 .\end{array}$ \\
\hline 15.91967 & $?$ & $\begin{array}{l}\text { Stryn, Nordfjord, two 1-m } \\
\text { high waves (fjord seiches). }\end{array}$ & $\begin{array}{l}\text { L - Cable break. Changes } \\
\text { in bathymetry }(+55 \mathrm{~m}) \text {. } \\
\text { Slide volume: } 15 \times 10^{6} \mathrm{~km}^{3}\end{array}$ & $\begin{array}{l}\text { Aarseth et al., 1989; } \\
\text { Furseth, } 2012 .\end{array}$ \\
\hline $\begin{array}{l}11.5 .2011 \\
\text { Tohoku }\end{array}$ & 9.0 & $\begin{array}{l}\text { Inner Sognefjord. } \\
\text { Duration } \sim 2.5-3 \mathrm{hrs}\end{array}$ & $\begin{array}{l}\mathrm{T} \text { - Observation-based } \\
\text { seiche modeling }\end{array}$ & Bondevik et al., 2015. \\
\hline
\end{tabular}

very large far-field earthquakes are able to trigger observable mass-wasting events on distant, unstable continental margins. They showed that the 2012 M 8.6 Indian Ocean earthquake triggered a sequence of slope failures, gravity flows and turbidity currents more than 13,500 km away on the Cascadia margin, continuing intermittently for four months. Similarly, Løvholt et al. (2018) have analysed the regional M 7.2 1929 Grand Banks earthquake and the subsequent slide off Newfoundland, displacing more than $100 \mathrm{~km}^{3}$ of slide material evolving into turbidity currents and tsunamis, affecting both the adjacent and the conjugate coasts.

By analogy, we infer that large teleseismic, regional and local paleoevents have had, and have, the power to induce secondary events in Fennoscandian fjords, coasts and lakes as well as along the Norwegian continental margin. We note that Mörner $(2005,2017)$ has reported several tsunamigenic earthquakes along the coast of Sweden, but also that Lund et al. (2017) have cast some doubt on these claims.

During historical times, many fjords and lakes have experienced rock avalanches (Lyså et al., 2009; Hermanns et al., 2013). A major inland event in central Norway reported by Wilson (2009) has been dated by the Schmidt hammer method to be of Late Holocene age, $1.825 \pm 0.76 \mathrm{ka}$. Despite the dating uncertainty, the rock movement is consistent with Late Holocene tectonic events observed elsewhere in Fennoscandia (Table 2).

Both local rock and soil avalanches and submarine mass wasting might induce flooding and local and regional tsunamis (Bondevik et al., 1997, 2020; Harbitz et al., 2013, 2014). An intriguing case is the 1967 
submarine slide in Nordfjord, $\sim 61.9^{\circ} \mathrm{N}, 7^{\circ} \mathrm{E}$ (Table 4), that broke telephone cables and changed the fjord bathymetry by as much as $55 \mathrm{~m}$, while three $\sim 1 \mathrm{~m}$-high waves flooded the adjacent shoreline (Aarseth et al., 1989; Furseth, 2012). However, none of the earthquake repositories report any potential trigger candidate for this seiche-like event. Thus, all seiches or seiche-like events may not arrive from seismic far-field events, nor be induced by local or regional earthquakes (e.g., Furseth, 2012; Olesen et al., 2013; Bellwald et al., 2016, 2018a). Possibly, some water waves, as exemplified by the Nordfjord disturbance in Table 4, may have originated from mass movement in unstable sediments or in onshore rock surfaces without an obvious external trigger. We denote such waves fjord-seiches.

\section{Societal consequences}

The local surface devastation of a large GLFP earthquake must have been considerable even in a poorly populated and developed epicentral area where early Mesolithic hunter-gatherers migrated onto new land as the ice retreated (Rydgren \& Bondevik, 2015). Moreover, some earthquakes may have triggered secondary phenomena with a potential to cause havoc along coast- and shorelines that presently might be observable by geological, geomorphological and societal proxies (Bøe et al., 2007; Table 1).

Despite probable local devastation within the GLFP proper, we consider the main impact on the societal environment to be of a secondary nature, induced by local and regional GLFP earthquakes in a setting where rapid sedimentation provides conditions for downslope mass movement both on- and offshore. During the past $125 \mathrm{ka}, \sim 50 \%$ of the total volume of submarine sediments were mobilised by extreme slope failure 15-8 ka ago (Korup, 2012), i.e., during deglaciation. Hence, an earthquake in this period is a viable trigger mechanism for release of onshore and submarine avalanches cascading downslope, at slopes preconditioned for failure. In turn, the large-scale mass wasting may have caused devastating tsunamis (Dawson \& Stewart, 2007) of potential extreme run-up heights (Harbitz et al., 2013). However, modelling of a complex retrogressive slide development shows that not all slides generate tsunamis ( Løvholt et al., 2017). Nonetheless, the disturbance of an earthquake, commonly facilitated by rising sea level, hydrate disassociation and instable sediments, may provide the final coup-de-grâce.

In addition to the hazard potential for coastal communities, today even larger potentials arrive from submarine slides and tsunamis as some offshore areas are commonly the location of hightechnology installations such as oil and electricity-producing platforms, submarine cables and pipelines (W. Fan et al., 2020). There is also a potential impact on the environment from petroleum spills. Thus, the consequences of mass wasting on a continental margin might be felt over a far larger coastal area than that of the actual slide.

\section{Mass-transport deposits}

Recently, attention has turned towards Holocene subaquatic paleoseismology in marine and lacustrine sediments in Canada and Chile (St-Onge et al., 2012) and in lake sediments in Switzerland (Strasser et al., 2013; Kremer et al., 2017). The methodology was applied to the Norwegian fjord and lake region, 59.5$63^{\circ} \mathrm{N}$; where glacimarine MTDs provide evidence of numerous mass-wasting events (e.g., Aarseth et al., 1989; Aarseth, 1997; Bøe et al., 2000, 2004; Bellwald et al., 2016). In this region, Bellwald et al. (2018a) showed that the postglacial MTD clusters occurred during 11.0-9.7 and 8.3-7.7 ka (Table 2, Fig. 4), with recurrence intervals of 80 yrs directly after the deglaciation and 200 yrs during the early Holocene. 


\section{Submarine slides}

The high-latitude glaciated margins are particularly prone to downslope mass wasting (Leynaud et al., 2009; Tappin, 2010), and a number of Quaternary and Holocene submarine paleoslides of greatly varying scales exist along the $N$ Atlantic passive margins (i.e., Hjelstuen et al., 2007; Normandeau et al., 2019) and have provided a slide inventory of the Norwegian continental margin. In particular, slides of varying areal extent, volume and depositional style characterise the margin during the Pleistocene, including megaslides (Vorren et al., 1998; Goff et al., 2014) such as the large, early Holocene, Storegga Slide (Fig. 1). Located $\sim 900 \mathrm{~km}$ from LFP, it is a contender for a regional GLFP or far-field earthquaketriggered event. We also note that three Pleistocene megaslides on the Barents Sea Margin $\left(\sim 71-73^{\circ} \mathrm{N}\right)$, far larger than the Storegga Slide, have been reported by Hjelstuen et al. (2007) who also mapped several smaller ones in the region $\sim 67-72^{\circ} \mathrm{N}$ (Fig. 1). The megaslides, as well as coeval seiches, tsunamis and turbidity currents, have left a distinct imprint on the $\mathrm{N}$ Atlantic coasts, continental margins and ocean basins (e.g., Lee, 2009; Urlaub et al., 2013). However, slide deposits are commonly poorly preserved and hard to find (e.g., Brothers et al., 2013; Polonia et al., 2015; Ratzov et al., 2015).

\section{Storegga Megaslide and tsunami}

We now return to the much-investigated Storegga Slide, which extends from the shelf edge to the oceanic Norway Basin (Fig. 1). It moved 3,000-3,500 $\mathrm{km}^{3}$ of sediments and affected an area of $\sim 95,000 \mathrm{~km}^{2}$ (Solheim et al., 2005a, b). The main retrogressive slide event occurred $8.1 \pm 0.25 \mathrm{ka}$ ago (Haflidason et al., 2005), later refined to $8.11 \pm 0.1$ ka by Dawson et al. (2011) and to 8.175-8.12 ka from tsunamigenic deposits, i.e., near the coldest decades of the 8.2 ka cold spell (Bondevik et al., 2012; Fig. 4). This abrupt cooling period is observed over large parts of the Northern Hemisphere. The temperature anomaly has been linked to the breakup of the ice barrier damming the proglacial Agassiz and Ojibway lakes, initiating a cold-water cascade into the Labrador Sea during a $\sim 0.5-5 \mathrm{ky}$ period (Matero et al., 2017; Fischer, 2020). The cooling is also detected in Greenland ice cores from 8.4.to $8.0 \mathrm{ka}$ by a $5-7^{\circ} \mathrm{C}$ fall in mean annual temperature over the central ice dome (Long et al., 2006; Rasmussen et al., 2006). Thus, the temporal affinity of the GLFP tremors and the Storegga Slide, lead us to explore a causal link.

In fact, a recent survey of 85 submarine slides in the Gulf of Mexico (W. Fan et al., 2020) revealed that the majority of the slides were dynamically triggered by arriving surface waves from distant earthquakes. Surprisingly, some events had magnitudes as small as M 5, and it appears that the transient strain perturbations from the passing waves lead to slope failure, in cases followed by tsunamis (Johnson et al., 2017; W. Fan et al., 2020).

Numerical modelling and tsunami deposits along the coasts of Scotland, Shetland, Faeroe Isles and Norway (Bondevik et al., 2003, 2005, 2012) support a coeval tsunamigenic event. The tsunami has been observed as far away as Finnmark in northernmost Norway (Romundset \& Bondevik, 2010; Bondevik et al., 2020), NW Barents Sea (Rüther et al., 2012), E Greenland (Wagner et al., 2006) and Denmark (Fruergaard et al., 2015). Run-up heights $>20 \mathrm{~m}$ are inferred in Shetland, and an early Stone Age settlement on the Norwegian coast covered by tsunami deposits suggests an 18-20 m run-up (Bondevik et al., 2003), whereas a minimum of 1-7 m is estimated at the head of Nordfjord (Vasskog et al., 2013). An event of this magnitude may also have devastated settlements elsewhere along the coasts, fjords and islands, and along the conjugate margin, noting that tsunami modelling off Svalbard shows that even relatively small slide volumes may generate wave heights threatening coastal settlements at far distances in NW Europe and E Greenland (Berndt et al., 2009). 
Although a Storegga seismic trigger mechanism is not considered proven, a link to deglaciation and GIA induced stress appear plausible factors, as suggested by many investigators. The slide location in the vicinity of older tectonic lineaments may also imply a relationship to structural reactivation and inheritance. In particular, Phillips et al. (2019) show a number of examples of structural inheritance in the northernmost North Sea. Fig. 3 shows an earthquake cluster (Byrkjeland et al., 2000) in the area where the North Sea N-S-trending Mesozoic fault system interacts with the older, Devonian and Mesozoic, NE-SW Møre-Trøndelag Fault Complex (MTFC) system (Doré et al., 1997; Gabrielsen et al. 1999; Olsen et al., 2007; NPD, 2020; Osmundsen et al., 2021), whereas the eastern branches of the MTFC are mostly aseismic at present. It is likely that this region experienced tectonic deformation during deglaciation, not least since some deformation is still ongoing (Fig. 3, Table 4). Landward, the cluster may be bounded by a coast-near segment of the presently seismically active $\varnothing$ ygarden Fault Zone (Tjåland \& Ottemöller, 2018). Another possibility is hidden thrusts having the capability to accommodate M 6.5-7 earthquakes without breaking the surface (Bungum et al., 2005). Nonetheless, Lindholm et al. (2005) state that the trigger mechanism for the Storegga Slide is not yet entirely resolved, in spite of extensive multidisciplinary studies related to the development of the Ormen Lange gas field, which is located within the slide area (Solheim et al., 2005a).

Importantly, the slide is also located in an area of proper boundary conditions for gas hydrate dissociation (Blunier et al., 1995; Mienert et al., 2001, 2005; Handwerger et al., 2017), and where overpressure is due to dense glacial sediments over a less dense substratum (Hjelstuen et al., 1999, 2007; Kvalstad et al., 2005; Siegel et al., 2014). In fact, Llopart et al. (2019) considered overpressure to be a critical precondition for slope failure.

The 8.1 ka Storegga Slide is the main event in a repetitive slide complex since the midPleistocene, comprising seven relatively large slides from the early Pleistocene to Younger Dryas (Bugge et al., 1987; Evans et al., 2005; Gauer et al., 2005; Solheim et al., 2005b). There are widespread tsunamigenic turbidites and debris flows in neighbouring fjords and lakes adjacent to the Storegga Slide, as well as deposits interpreted to reflect an older, possibly earthquake-related tsunami dated to $11.7-$ $11.0 \mathrm{ka}$, possibly triggered by a local earthquake (Bøe et al., 2004). Other tsunami-like deposits occur in SW Norway, where the Stone Age settlement at Galta ( $\left.59.35^{\circ} \mathrm{N}, 59.07^{\circ} \mathrm{E}\right)$ experienced $2.5-4 \mathrm{~m}$ run-up during the 11.2-11.5 ka period, probably caused by a local slide (Bøe et al., 2000, 2007).

The fact that the Storegga Slide occurred at the younger end of the relatively uncertain age range of the large GLFP events (Fig. 4) does not rule out a regional or teleseismic trigger, nor can we rule out that a local earthquake may have triggered the slide and subsequent tsunami (Bellwald et al., 2018a; Vestly, 2017). Furthermore, the GLFP earthquakes may have released one or more of the precursor slides further destabilising a continental slope prone to failure, thus setting the stage for the main slide event. Another alternative is a large far-field event, from which seismic waves travelled thousands of kilometres (e.g., Table 3). Even so, the magnitude of the GLFP events and the relatively short epicentral distance, $\sim 900 \mathrm{~km}$, to the Storegga Slide make a GLFP event, in our opinion, a preferred trigger candidate where the seismic tremors arrived at a margin primed for failure, leaving both a local and a regional tsunamigenic imprint. Nonetheless, the temporal relationship to the $8.2 \mathrm{ka}$ cold spell is indeed a tempting scenario. If so, the cold spell might have loaded the continental margin with excessive amounts of high-density glacial debris above more biogenic material, destabilising the slope and thus priming the margin for failure.

A related question is whether there is a temporal coincidence of the rapid early Holocene sealevel rise (Figs. 2, 4) and large-scale slope failures. Brothers et al. (2013) claim that such a link is well documented and that the stress on passive margins may have increased by $>1 \mathrm{MPa}$ during the rise of sea level, in turn triggering fault reactivation, rupture and earthquakes. On the other hand, Urlaub et al. (2013) and Pope et al. (2015) argued that the slide dates do not support this scenario because there is 
no valid statistical relationship between rapid sea-level rise and large slide frequency; and that the accuracy of slide dating does not allow a correlation, if existing. Finally, modelling shows that a $2^{\circ} \mathrm{C}$ cooling of the bottom water by lowering sea level during glaciation is compensated by the sea-level change during deglaciation (Screaton et al., 2019).

\section{Rock avalanches}

GLFP tremors may have triggered some of the numerous rock avalanches typical for coastal Norway (e.g., Valagussa et al., 2019). Rock-avalanche deposits landward of the Storegga Slide (Fig. 1) show a majority of events and rock volumes during the deglaciation, returning to a constant low level thereafter (Longva et al., 2009). On the other hand, Böhme et al. (2015) inferred a high failure frequency just after deglaciation without any large events during the past $9 \mathrm{ka}$. In the same area, Hilger et al. (2018) reported catastrophic rock-slope failures during deglaciation 12-10 ka ago, followed by an event cluster at $4.9 \pm 0.6 \mathrm{ka}$ (cosmogenic ages) related to the climate change at the end of the Holocene thermal optimum.

Thus, we find it reasonable to suggest a temporal link between rock avalanches and deglaciation for which GLFP earthquakes might provide the release mechanism.

\section{Flooding}

Besides the potentially significant near-regional hydrological effects from large earthquakes, especially normal-faulting ones (Muir Wood \& King, 1993), secondary events also include sudden flooding by paleoearthquake-triggered breakup of ice or sediment barriers that have approached an instability level, and/or changing drainage patterns initiating a coeval flooding event (Table 3). The most well-known example is from $\mathrm{N}$ America where a superlake-megaflood catastrophic event occurred when the Agassiz and Ojibway ice lakes, that had existed for 4000 years, broke the Laurentide ice-sheet barrier 8.45 ka ago, thus being drained near the onset of the 8.2 ka cold spell (Fig. 4; Barber et al., 1999; Clarke et al., 2003; Gregoire et al., 2012). Such an event could well have been triggered by an earthquake, albeit not likely from GLFP, causing freshwater floods through the Hudson Bay towards the N Atlantic, possibly disrupting the Atlantic Meridional Overturn Circulation (Elmore et al., 2015; Lippold et al., 2019). Megafloods have also been proposed to have caused Pliocene-Pleistocene megacanyons in Greenland (Keisling et al., 2020). Another ice-dammed glacial outburst occurred in the N North Sea during the early phase of deglaciation (Hjelstuen et al., 2018) in the vicinity of the much older, 130 ka, Tampen Slide (Bellwald et al., 2018b).

In Norway, Olesen et al. (2013) noted that indications of neotectonism based on liquefaction and gravitational faulting may suggest earthquake activity. A similar, regional phenomenon is related to a 11.5 ka M 7.5 earthquake in Lake Vättern which occurred following a catastrophic drainage of the Baltic Ice Lake when the Fennoscandian ice sheet, damming the lake, retreated at the end of the Younger Dryas, 11.7 ka (Björck, 1995). When the ice barrier failed, as much as $7800 \mathrm{~km}^{3}$ lake water drained to the North Sea during a 1-2-year period (Jakobsson et al., 2007). We note that Jakobsson et al. (2014) speculate that rapid offloading by a melting ice barrier released stress that could have induced an earthquake, triggering the catastrophic $25 \mathrm{~m}$ drainage of lake water. We agree that the rapidity of the offloading could have played a role. Another, perhaps more likely, cause-andeffect scenario applicable to ice and/or sediment barriers in general, is that an earthquake may have structurally weakened the barrier providing conditions for break-up of a primed, loaded lake system. We also note that Mörner (1996) reported a paleoseismic event generating a tsunami at $13 \mathrm{ka}$, and that the Lansjärv Fault (Fig. 1; Wahlström \& Kulhánek, 1983) may be tsunamigenic as it is partly located below the highest Baltic Sea shoreline (Kukkonen et al., 2010). 
Flooding during deglaciation is also documented in southeastern Norway by the huge, catastrophic Nedre Glomsjø outburst flood (Høgaas et al., 2017; Hansen et al., 2020), as well as in the N and NE Scandinavian mountains (Regnéll et al., 2020). The huge Nedre Glomsjø glacial lake, in particular, was dammed to the south by an ice barrier which broke 10.4-10.0 ka ago (Fig. 4). The lake drainage moved huge masses of water and ice, $100 \mathrm{~km}^{3}$ (Longva, 1994), through the Jutulhogget Canyon and into the valley below, and beyond (Høgaas \& Longva, 2016, 2018). Probably, the huge flood caused havoc downstream, wiping out early hunters and their settlements. In fact, we might speculate that a GLFP earthquake triggered the outburst flood.

\section{Pockmark fields}

Gas-hydrate dissociation during the Last Glacial Maximum may have contributed to increasing the frequency of slumping on the continental margins due to methane release and development of excess pore pressure (Carpenter, 1981). At high latitudes, gas-hydrates commonly create domes (hydrate-pingos). Temperature increase or pressure reduction will destabilise the hydrates, causing dome collapse and crater formation at the sea floor, i.e., pockmarks (Andreassen et al., 2017). A comprehensive overview of pockmarks and seepages in the North Sea has been presented by Hovland \& Judd (1988).

Now, we draw attention to one of the world's largest pockmark fields, the Troll Field in the northern North Sea (Fig. 1), for which carbonate geochemistry and hydrate stability analyses make gas-hydrate dissociation a likely trigger (Mazzini et al., 2017). Presently, the field is without active gas seepage, but geochemical analysis of carbonate blocks within the pockmarks suggests a methanogenic origin from past hydrate dissociation and fluid venting at the seafloor. U-Th dates of the carbonates constrain the pockmark formation to $9.59 \pm 1.38 \mathrm{ka}$ (Fig. 4), consistent with radiocarbon dating of microfossils. Thus, Mazzini et al. (2017) inferred that the last deglaciation was an external force triggering the gas-hydrate dissociation forming the large pockmark field.

Several other pockmark fields along the Norwegian margin have been related to deglaciation. Among these are the apparently older Nyegga pockmark field, just north of the Storegga Slide (Fig. 1), dated as $<16.2$ and 19-16 ka by Hjelstuen et al. (2010) and Hustoft et al. (2009), respectively. In fact, Hustoft et al. (2009) suggested rapid sediment loading as a trigger mechanism, but also indicate earthquakes as a potential trigger. In the $\mathrm{W}$ Barents Sea, large pockmark fields are associated with deglaciation (Andreassen et al., 2017; Waage et al., 2019), and a field in the Witch Ground Basin in the central North Sea may have been triggered by external forces related to postglacial environmental change (Böttner et al., 2019).

We agree that deglaciation plays a role in gas seepage and venting, noting that Malinverno et al. (2018) suggested that marine methane hydrates form in sediments deposited during glacials due to enhanced microbial activity, thus without having a deeper source. In fact, pulses of increased sedimentation controlled the hydrate stability and triggered widespread gas dissociation during the end of the last glaciation (Karstens et al., 2018). Nonetheless, the persistently slow nature of deglaciation over large areas lead us to consider a transient external trigger, possibly related to the passing of a temperature-pressure threshold perturbing the Gas Hydrate Stability Zone (GHSZ) by reducing its thickness. In fact, any change in hydrostatic pressure influences the stability of methane seepage. Note, in particular, that active faulting and slumping can alter the seepage dynamics (Hovland \& Judd, 1988; Yelisetti et al., 2014; Waage et al., 2019). Thus, making the GHSZ sediments susceptible to mechanical failure induced by seismic activity (Yanchilina et al., 2018; W. Fan et al., 2020; Hillman et al., 2020), enhancing permeability (Kinoshita \& Saffer, 2018; Ren et al., 2020) and creating pathways for gas expulsion from below the Bottom Simulating Reflector, in turn causing hydrocarbon venting and pockmark formation (Fig. 5). 


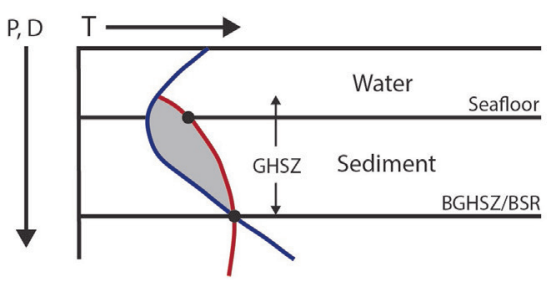

Fig. 5. Schematic diagram of a gas hydrate setting. Red and blue curves are the gas-hydrate phase boundary and the therma gradient, respectively. Stable hydrate to the left of the phase boundary. Shaded area: area of potential hydrate occurrence. GHSZ: Gas Hydrate Stability Zone; BHGSZ: Base Gas Hydrate Stability Zone; BSR: Bottom Simulating Reflector (separating hydrate-cemented sediment above and un-cemented sediment below). P: pressure; D: depth; T: temperature. Based on Kvenvolden (1993), Wang et al. (2017) and You et al. (2019).

A similar mechanism has been suggested for the continental margin off Pakistan (Editorial, 2013), where the proposed trigger was the large Nov. 28, 1945, M 8.1 Makran earthquake that led to substantially enhanced gas seepage during the subsequent few decades (Fischer et al., 2013). We note that microseismic events have been related to gas migration and seepage on the W Svalbard margin (Franek et al., 2017), and mud volcanoes are commonly thought to be triggered and modulated by earthquakes (Bonini et al., 2016; Maestrelli et al., 2017). Interestingly, Mörner (2017) relates explosive methane hydrate venting in crystalline bedrock during deglaciation in Sweden to earthquakes hundreds of kilometres away.

If removal of the ice sheet changed the hydrate stability conditions towards a threshold state, the timing of the Troll pockmark field is consistent with a large GLFP earthquake triggering gas expulsion and pockmark formation. In this setting, we prefer a large teleseismic or regional event due to that the better developed, and longer lasting shear and surface waves, are a most effective deformation agent (Manga et al., 2009; W. Fan et al., 2020). Importantly, experimental results by Namiki et al. (2018) show the importance of external seismic waves from large earthquakes driving volcanic edifice resonance and subsequent propagation of variably buoyant cracks (Jolly, 2019). Furthermore, giant lake pockmarks in Switzerland formed by subsurface fluids have been correlated with historical seismicity when the minimum microseismic intensity is VII (Reusch et al., 2016).

We believe that an external trigger mechanism might induce both pockmark fields and submarine slides, noting the analogies with the Gulf of Mexico (W. Fan et al., 2020) and Swiss lakes (Reusch et al., 2016). Moreover, Lupi et al. (2013) suggested that the Lusi mud eruption in Indonesia was mobilised by geometric focusing of seismic waves from the 2006 Yogyakarta earthquake located 250 km from Lusi, and Manga et al. (2009) considered earthquakes to be a viable trigger for mud volcanoes. However, an earthquake driver is contested as the Lusi eruption has been related to a blowout in a nearby well (Davies, 2018; Tingay et al., 2018) and to deep hydrothermal activity (Malvoisin et al., 2018). Moreover, Sawi \& Manga (2018) admit that seismically triggered explosive eruptions may occur less frequently than previously reported. Reduced hydrate stability conditions could have facilitated, or contributed, to the Storegga Slide slope failure (Mienert et al., 2005). Thus, it is possible that a large earthquake, for example in the GLFP, was the trigger mechanism for both the Storegga Slide and the Troll pockmark field, both regions that became increasingly instable due to temperature-related phenomena and rapid sedimentation and, thus, prone to failure.

Release of $\mathrm{CO}_{2}$ and methane to the atmosphere would increase global temperatures by release of climate gases, in turn inducing ice melting; i.e., a positive feedback loop enhancing global warming (Heimann, 2010). Noting that submarine gas release is a mechanism for exporting climate gases to the hydrosphere, Ruppel \& Kessler (2017) argued that the warming climate is not a plausible cause for catastrophic breakdown of global hydrates releasing methane to the atmosphere. Thus, warming climate may be a condition for hydrate dissociation and pockmarks, but without appreciable impact on atmospheric greenhouse gases (Hopcroft, 2017). If the magnitude estimates of the large postglacial GLFP earthquakes are representative, the methane gas release caused by a single event 
may affect regional climate. If so, there has to be a reliable temporal link between the earthquake and geological climate proxies and/or verifiable consequences for environment and human society. However, the sparsely populated northern regions in the early Holocene combined with removal and/ or redeposition of sediments blanketing bedrock make earthquake dates as well as hazard and damage assessments problematic, particularly in terms of climate.

\section{Discussion}

Our overview shows a regional response to the early Holocene deglaciation in northern Fennoscandia that potentially was triggered by a series of paleoearthquakes in a wide-ranging region. In an accompanying review (Eldholm and Bungum, in prep.) we show that, in a first-order sense, observational data and numerical modelling are consistent with a GIA response to ice load removal from the surface of thick old lithosphere during deglaciation. Moreover, the lithospheric response to load removal reflects the temporal and spatial ice load distribution, as well as a favourable orientation of the rebound stress with respect to the early Holocene ambient stress field and pre-existing mechanically weak structures. The quality of the GIA model depends critically on the ability to image the subsurface and its ice load, and on other lateral effects such as displaced eroded sediments and bedrock. Thus, ice removal, rebound and earthquakes exemplify a climate-earthquake causal sequence, being part of an early Holocene complex system of coupled Earth processes. Since deglaciation is only one part of the glacial cycle, its predecessor, the build-up of ice sheets, with the potential of suppressing lithospheric stress and delaying stored tectonic stress release, may also contribute to the deformation and seismicity during deglaciation.

In terms of earthquakes and climate, via deglaciation, the most compelling observation is the spatial relationship between major glacial load changes, GIA and rejuvenation of old structures in the Lapland Fault Province and beyond. However, early Holocene faulting during deglaciation occurred also outside the LFP as defined by Lagerbäck \& Sundh (2008). In particular, the Jämtland and Bollnäs faults and the Lake Vättern Graben, as well as well-documented landforms and landslides linked to fault scarps support deformation beyond the LFP. Thus, we have recognised the importance of extending the LFP to what we have named the Greater Lapland Fault Province.

We show that the main seismic activity in the GLFP occurred during the 11.5-8.2 ka period, clustered at 10-9 ka, and with coeval moment magnitudes in the $~ 5.5-8.4$ range (Fig 4; Table 2). This period is consistent with the finite element modelling of Wu et al. (1999), who inferred that postglacial rebound induced strain may have reactivated large old thrust faults in bedrock during a $\sim 4$ ka period of instability during 13-9 ka, with a maximum at $\sim 11-9$ ka. Nonetheless, we stress that the dating and magnitude assignments of many features have considerable uncertainty, and we consider the GLFP date ranges in Table 2 and Fig. 4 as qualitative at present. Moreover, local and regional variability in the timeregressive retreat of the Fennoscandian ice sheet may explain some of the scatter in the data.

We infer that some landforms and landslides in the period $\sim 8.0-5.5 \mathrm{ka}$, i.e., as much as $\sim 3-4 \mathrm{ka}$ after deglaciation, are likely to be earthquake triggered if associated with adjacent fault scarps. However, some of the landslides have very low-angle sliding planes. Thus, we follow Mikko et al. (2015) who stressed that surficial information may not yield the amount and quality of data without an associated faulted bedrock surface (Fig. 1). We consider these event ages less certain than those of the postglacial events in GLFP that are mainly based on structural deformation of bedrock faults. In fact, it is difficult to distinguish non-earthquake related flooding events from events related to liquefaction processes, driving mass movements at low angles. Therefore, fault-scarp-based dates and those of above-lying sediments become essential. The causes of some of these younger events are most likely short-lived climatic events related to glacial advance and retreat, or possibly by relatively large 
local and/or regional glaciers left behind. Nonetheless, analysis of datable MTDs provide an avenue for addressing such issues (Talling, 2021).

The apparent spatial relationship between paleoearthquakes and ancient structural and/or compositional upper-crustal lineaments and boundaries is consistent with the notion that structural inheritance and rejuvenation played a key role in the crustal deformation during deglaciation.

We suggest two avenues for mitigating the general lack of early Holocene geological data, in particular reliable fault dates. First, continue targeted drilling into some of the major GLFP faults to improve fault parameters and dates (Kukkonen et al., 2011; Ask et al., in press), and second, to expand high-resolution profiling of faults in lakes and inland seas where young sediments might be cored, thus providing reliable deformation ages (e.g., Hutri \& Kotilainen, 2007; Jakobsson et al., 2014; Gràcia et al., 2017; Olsen \& Høgaas, 2020).

The issue of magnitude assessments of the early Holocene earthquakes is also of importance, where a default assumption earlier has been that they represent whole-scarp ruptures, with magnitudes derived from the estimated physical properties (fault area, slip and rigidity). Olesen et al. (in press) have shown, however, that a single-rupture hypothesis is not likely to be correct for the SFC, but that it still has the potential for large magnitudes (6.4-8.0). Also, Smith et al. (in press) find that the hypothesis is not valid for many of the high-relief fault scarps in northern Sweden, supporting earlier suggestions of Smith et al. (2018) and Mattila et al. (2019). The single rupture is an end-member hypothesis that is never strictly true for postglacial earthquakes. However, it remains a fact that these events represent an extraordinary burst of seismic moment release over a very short time, not equalled by other tectonic processes. From basic earthquake scaling laws we know that it would take more than $30 \mathrm{M7}$ earthquakes to account for the seismic moment released by an M 8 earthquake, which in turn tells us that very large earthquakes are still needed to explain the structures in the GLFP even if they represent a multi-rupture feature. Thus, we conclude that segmentation may not have a significant influence on the potentials of secondary effects discussed here.

We infer that rebound is a satisfactory condition for early Holocene rupturing, but that local, ambient tectonic stress and old weak structures are necessary to explain both the early Holocene paleoseismicity, and the present seismicity, in Fennoscandia. Moreover, we maintain that the dominant forces acting on Fennoscandia, at present and during deglaciation, are those related to plate tectonics, to ridge-push, and to lateral variations in lithospheric structure and related loads, at different wavelengths.

We concur with the many investigators who have suggested that an earthquake might have triggered the Storegga Slide and its coeval tsunami, as well as other slides along the margin, for which we consider GLFP events as the most likely trigger candidates. In fact, the temporal affinity of the Storegga Slide with the 8.2 ka cold spell might have facilitated the instability of the margin during decreasing temperatures by increasing the deposition of dense glacial material. A GLFP event may also have triggered some of the Storegga predecessors, and by analogy, a similar sequence of events may apply to high-latitude continental margins elsewhere.

The dating of the pockmarks within the huge Troll pockmark field in the northern North Sea as well as other fields along the continental margin and in the Barents Sea might suggest an external trigger for which GLFP earthquakes is a potential candidate. Finally, we consider that a GFLP event might be responsible for local and regional flooding, and in particular, the catastrophic drainage of the Baltic Sea Lake, and possibly for some other events during a period 3-4 ka after the ice retreated. The latter indicate the existence of a potential mid-Holocene event period. Moreover, some observations in Finland and along the SFC may suggest additional reactivation during the past millennium (Fig. 4; Table 2). 
A key question is whether some transient events are caused by earthquakes, or secondary events forced by earthquakes, and whether some local and regional earthquakes are coeval with other global transient events. Cause-and-effect relations may also depend on poorly understood feedback mechanisms and thresholds (Fyke et al., 2018). Thus, climate change may induce earthquakes whereas earthquakes, via deglaciation, may also modulate climate by changes in topography and in the transfer of water masses in cases changing ocean circulation, i.e., a classical chicken-and-egg scenario (e.g., Eldholm \& Coffin, 2000; Tuffen \& Betts, 2010; Cooper et al., 2018; Fig. 4).

At high northern latitudes, some secondary far-field effects may be far more destructive than those in the scarcely populated epicentral regions. However, whether a catastrophic event occurs, or not, depends on the prevailing states of the lithosphere, atmosphere and not the least, society. Hence, earthquakes may uproot stable cultures or societies leading to diaspora and even new socialeconomical-cultural systems. One or a series of earthquakes may trigger social overturn if it is coeval with periods of social tension, unrest or economic decline (Nur, 2002), to which we add climate deterioration.

During the early Holocene, the secondary effects from distant and regional earthquakes may have caused far more devastation than those in the Mesolithic epicentral areas. The present highlatitude continental margins, with its many high-tech installations, are particularly prone to earthquaketriggered mass wasting caused by sediment instability, overpressure, and conditions for gas hydrate dissociation. The North Atlantic margins have a blanket of dense glacial sediments over less dense material, a setting that may further amplify the mass wasting and tsunami potential, i.e., an earthquake-slide-tsunami causal sequence.

Finally, our analysis shows that the early Holocene (Fig. 4) is a prime period for analysing global, regional and local potential relationships of both sudden, transient events and more persistent trends. However, many potential temporal and causal links are still uncertain. Among the many transient events during this period, some may have affected human settlements and societies. In particular, the 9-11 ka earthquake cluster warrants further consideration, again realising that cause-and-effect relationships may include complex feedback mechanisms.

\section{Conclusions}

In this overview we have analysed paleoearthquakes in Fennoscandia during the last deglaciation with emphasis on the potential secondary effects that such events might have initiated. In particular, we have found clear indications of events beyond the previously mapped Lapland Fault Province (LFP) of Lagerbäck \& Sundh (2008). We have named the expanded zone, the Greater Lapland Fault Province (GLFP).

We propose that secondary effects may encompass surface rock avalanches, submarine slides of various dimensions, local and regional flooding events, and tsunamis generated both by rock avalanches in fjords and by large submarine slides. We agree with those who link the large Storegga Megaslide with an earthquake and suggest an earthquake from the GLFP as a candidate for triggering both the Storegga Megaslide and its predecessors. As for Storegga, we suggest that the GLFP earthquakes might have also triggered many of the other events discussed in this article.

There is now increasing evidence weakening the earlier assumptions that the large postglacial earth-quakes were single-rupture events which, however, is found by us not necessarily to have any significant influence on the potentials for secondary effects. 
For triggering of secondary events we suggest that a climate-earthquake-slide-tsunami causal sequence is particularly important, as is both structural inheritance and rejuvenation.

The continental margins off Norway, Barents Sea and Svalbard are characterised by areas of pockmarks reflecting water and gas expulsion. Possibly, the GLFP earthquakes triggered some of these events.

While the 11-9 ka period appears to comprise most GLFP earthquakes, we stress that both dates, characters and magnitudes of individual GLFP faults and earthquakes need to be better understood in order to underpin more definite cause-and-effect relationships. Some of the secondary events may have been catastrophic for those inhabiting the affected areas, even if the high-latitude northern regions were sparsely populated during the early Holocene.

Acknowledgements. We are grateful to Odleiv Olesen (NGU) and Colby Smith (SGU) for providing updated coordinates for postglacial faults, and to Carl Fredrik Forsberg (NGI) for providing the outline of the Storegga Slide. The fault data can be downloaded from: https://doi.pangaea.de/10.1594/ PANGAEA.922705 (Munier et al., 2020). We also thank several chapter authors of a forthcoming Cambridge University Press book (Steffen et al., in press) for providing preprints, and to Sverre Planke and Benjamin Bellwald for providing the outline of the Troll and Nyegga pockmark fields. We thank Haflidi Haflidason, Yngve Kristoffersen, Conrad Lindholm and Emilie Randeberg for assistance and valuable advice. Figs. 1 and 3 have been made with Generic Mapping Tools (GMT), Version 6, Modern Mode (Wessel et al., 2019). Constructive and detailed reviews from Odleiv Olesen and Björn Lund are gratefully acknowledged.

\section{References}

Aarseth, I. 1997: Western Norwegian fjord sediments; age, volume, stratigraphy, and role as temporary depository during glacial cycles. Marine Geology 143, 39-53.

https://doi.org/10.1016/S0025-3227(97)00089-3.

Aarseth, I., Lønne, $\varnothing$. \& Giske ødegaard, O. 1989: Submarine slides in glaciomarine sediments in some western Norwegian fjords. Marine Geology 88, 1-21. https://doi.org/10.1016/0025-3227(89)90002-9

Abdi, A., Heinonen, S., Juhlin, C. \& Karinen, T. 2015: Constraints on the geometry of the Suasselkä post-glacial fault, northern Finland, based on reflection seismic imaging. Tectonophysics 649, 130-138. https://doi.org/10.1016/j.tecto.2015.03.004.

Ahjos T. \& Uski M. 1992: Earthquakes in Northern Europe in 1375-1989. Tectonophysics 207(1-2), 1-23. https://doi.org/10.1016/0040-1951(92)90469-M.

Andreassen, K., Hubbard, A., Winsborrow, M., Patton, H., Vadakkepuliyambatta, S.A., PlazaFaverola, A., Gudlaugsson, E., Serov, P., Deryabin, A., Mattingsdal, R., Mienert, J. \& Bünz, S. 2017: Massive blow-out craters formed by hydrate-controlled methane expulsion from the Arctic seafloor. Science 356, 948-953. https://doi.org/10.1126/science.aal4500.

Arvidsson, R. 1996: Fennoscandian earthquakes: whole crustal rupturing related to postglacial rebound. Science 274, 744-746. https://doi.org/10.1126/science.274.5288.744. 
Ask, M., Kukkonen, I., Olesen, O., Lund, B., Fagereng, Å., Rutqvist, J.-E. Rosberg, J.-E. \& Lorenz, H. in press: Proposed Drilling into Postglacial Faults: The Pärvie Fault System. In Steffen, H., Olesen, O. \& Sutinen, R. (eds.): Glacially-triggered Faulting, Cambridge University Press.

Baker, V.R. 2002: The study of superfloods. Science 295, 2379-2380.

https://doi.org/10.1126/science.1068448.

Bard, E., Hamelin, B., Arnold, M., Montaggioni, L., Cabioch, G., Faure, G. \& Rougerie, F. 1996: Deglacial sea-level record from Tahiti corals and the timing of global meltwater discharge. Nature 382, $241-244$. https://doi.org/10.1038/382241a0.

Barber, D.C., \& 10 others 1999: Forcing of the cold event of 8,200 years ago by catastrophic drainage of Laurentide lakes. Nature 400, 344-348. https://doi.org/10.1038/22504.

Båth, M., 1953: Seismicity of Fennoscandia and related problems. Gerlands Beiträge zur Geophysik 63, 173-208.

Bellwald, B., Hjelstuen, B.O., Sejrup, H.P. \& Haflidason, H. 2016: Holocene mass movements depositional environments in a high-latitude fjord system - Hardangerfjorden, Western Norway. Marine Geology 379 , 157-175. https://doi.org/10.1016/j.margeo.2016.06.002.

Bellwald, B., Hjelstuen, B.O., Sejrup, H.P., Stokowy, T. \& Kuvås, J. 2018a: Holocene mass movements in west and mid-Norwegian fjords and lakes. Marine Geology 407, 192-212. https://doi.org/10.1016/j.margeo.2018.11.007.

Bellwald, B., Urlaub, M. Hjelstuen, B.O., Sejrup, H.P., Sørensen, M.B., Forsberg, C.F. \& Vanneste, M., 2018b: NE Atlantic continental slope stability from a numerical modeling perspective. Quaternary Science Reviews 203, 248-265. https://doi.org/10.1016/j.quascirev.2018.11.019.

Berglund, M. \& Dahlström, N. 2015. Post-glacial fault scarps in Jämtland, central Sweden. Geologiska Föreningen i Stockholm Förhandlingar 137, 339-343.

https://doi.org/10.1080/11035897.2015.1036361.

Berndt, C., Brune, S., Nisbet, E., Sobolev, S. \& Zschau, J. 2009: Tsunami modeling of a submarine landslide in the Fram Strait. Geochemistry, Geophysics, Geosystems 10, Q04009. https://doi.org/10.1029/2008GC002292.

Björck, S. 1995: A review of the history of the Baltic Sea, 13.0-8.0 ka BP. Quaternary International 27, 19-40. https://doi.org/10.1016/1040-6182(94)00057-C.

Blunier, T., Chappellaz, J., Schwander, J., Stauffer, J. \& Raynaud, D. 1995: Variations in atmospheric methane concentration during the Holocene epoch. Nature 374, 46-49.

https://doi.org/10.1038/374046a0.

Böhme, M., Oppikopfer, T., Longva, O., Jaboyedoff, M., Hermanns, R.L. \& Derron, M.-H. 2015: Analyses of past and present rock slope instabilities in a fjord valley: Implications for hazard estimations. Geomorphology 248, 464-474. https://doi.org/10.1016/j.geomorph.2015.06.045.

Böttner, C., Berndt, C., Reinardy, B.T.I., Geersen, J., Karstens, J., Bull, J.M., Callow, B.J., Lichtschlag, A. Schmidt, M., Elger, J., Schramm, B. \& Haeckel, M. 2019: Pockmarks in the Witch Ground Basin, central North Sea. Geochemistry, Geophysics, Geosystems 20, 1698-1719. https://doi.org/10.1029/2018GC008068. 
Bondevik, S., Hovden, E., Svevad, S. \& Longva, O. 2020: Evidence of prehistoric landslide-generated tsu namis in the outer parts of Storfjorden, Western Norway (abs.). Geological Society of Norway, Abstract Proceedings No 1, p33.

Bondevik, S., Gjevik, B. \& Sørensen, M.B. 2015: Norwegian seiches from the giant 2011 Tohoku earthquake. Geophysical Research Letters 40, 3374-3378. https://doi.org/10.1002/grl.50639.

Bondevik, S., Løvholt, F., Harbitz, C., Mangerud, J., Dawson, A. \& Svendsen, J.I. 2005: The Storegga Slide tsunami - comparing field observations with numerical simulations. Marine and Petroleum Geology 22, 195-208. https://doi.org/10.1016/j.marpetgeo.2004.10.003.

Bondevik, S., Mangerud, J., Dawson, S., Dawson, A. \& Lohne, Ø. 2003: Record-breaking height for 8000-year-old tsunami in the North Atlantic. Eos 84, 289-293. https://doi.org/10.1029/2003EO310001.

Bondevik, S., Stormo, S.K. \& Skjerdal, G. 2012: Green mosses date the Storegga tsunami to the chilliest decades of the 8.2 cold event. Quaternary Science Reviews 45, 1-6.

https://doi.org/10.1016/j.quascirev.2012.04.020.

Bondevik, S., Svendsen, J.I. \& Mangerud J. 1997: Tsunami sedimentary facies deposited by the Storegga tsunami in shallow marine basins and coastal lakes. Sedimentology 44, 1115-1131.

https://doi.org/10.1046/j.1365-3091.1997.d01-63.x.

Bonini, M., Rudolph, M.L. \& Manga, M., 2016: Long- and short-term triggering and modulation of mud volcano eruptions by earthquakes. Tectonophysics 672, 190-211.

https://doi.org/10.1016/j.tecto.2016.01.037.

Bradley, K. \& 14 others 2019: Earthquake-triggered 2018 Palu Valley landslides enabled by wet rice cultivation. Nature Geoscience 12, 935-939. https://doi.org/10.1038/s41561-019-0444-1.

Brandes, C., Plenefisch, T., Tanner, D.C., Gestermann, N. \& Steffen, H. 2019: Evaluation of deep crustal earthquakes in northern Germany - Possible tectonic causes. Terra Nova 31, 83-93.

https://doi.org/10.1111/ter.12372.

Broeckx, J., Rossi, M., Lijnen, K., Campforts, B., Poesen, J. \& Vanmaercke, M. 2020: Landslide mobilization rates: A global analysis and model. Earth-Science Reviews 201, https://doi.org/10.1016/j.earscirev.2019.102972, 15 pp.

Brothers, D.S., Luttrell, K.M. \& Chaytor, J.D. 2013: Sea-level-induced seismicity and submarine landslides occurrence. Geology 41, 979-982. https://doi.org/10.1130/G34410.1.

Bugge, T., Befring, S., Belderson, H.R., Eidvin, T., Jansen, E., Kenyon, N.H., Holtedahl, H. \& Sejrup, H.P. 1987: A giant three-stage submarine slide off Norway. Geo-Marine Letters 7, 191-198.

https://doi.org/10.1007/BF02242771.

Bungum, H. \& Lindholm, C. 1996: Seismo- and neotectonics in Finnmark, Kola Peninsula and the southern Barents Sea. Part 2: seismological analysis and seismotectonics. Tectonophysics 270, 15-28. https://doi.org/10.1016/S0040-1951(96)00139-4.

Bungum, H. \& 8 others 2000: New Seismic Zoning Maps for Norway, the North Sea, and the United Kingdom. Seismological Research Letters 71, 687-697. https://doi.org/10.1785/gssrl.71.6.687. 
Bungum, H., Lindholm, C. \& Dahle, A. 2003: Long period ground motions for large European earthquakes, 1905-1992, and comparisons with stochastic predictions. Journal of Seismology 7, 377-396. https://doi.org/10.1023/A:1024505229355.

Bungum, H., Lindholm, C. \& Faleide, J.I. 2005: Postglacial seismicity offshore mid-Norway with emphasis on spatio-temporal-magnitudal variations. Marine and Petroleum Geology 22, 137-148. https://doi.org/10.1016/j.marpetgeo.2004.10.007.

Bungum, H. \& Olesen, O. 2005: The 31st of August 1819 Lurøy earthquake revisited. Norwegian Journal of Geology 85, 245-252.

Bungum, H., Pascal, C., Olesen, O., Lindholm, C., Vestøl, O. \& Gibbons, S., 2010. To what extent is the present seismicity of Norway driven by postglacial rebound? Journal of the Geological Society of London 167, 373-384. https://doi.org/10.1144/0016-76492009-009.

Bungum, H., Pettenati, F., Schweitzer, J., Sirovich, L. \& Faleide, J.I. 2009: The 23 October 1904 MS 5-4 earthquake: Reanalysis based on macroseismic and instrumental data. Bulletin of the Seismological Society of America 99, 2836-2854. https://doi.org/10.1785/0120080357.

Bungum, H. \& Selnes P.B. 1989: ELOCS - Earthquake Loading on the Norwegian Continental Shelf. NORSAR and Norwegian Geotechnical Institute, Summary Report, 38pp.

Byrkjeland, U., Bungum, H. \& Eldholm, O. 2000: Seismotectonics of the Norwegian continental margin. Journal of Geophysical Research 105, 6221-6236. https://doi.org/10.1029/1999JB900275.

Bøe, R., Hovland, M., Instanes, A., Rise, L. \& Vasshus, S. 2000: Submarine slide scars and mass movements in Karmsundet and Skudenesfjorden, southwestern Norway: morphology and evolution. Marine Geology 167, 147-165. https://doi.org/10.1016/S0025-3227(00)00017-7.

Bøe, R., Longva, O., Lepland, A., Blikra, L.H., Sønstegaard, E., Haflidason, H., Bryn, P. \& Lien, R. 2004: Postglacial mass movements and their causes in fjords and lakes in Norway. Norwegian Journal of Geology 84, 35-55.

Bøe, R., Prøsch-Danielsen, L., Lepland. A., Harbitz, C.B., Gauer,P., Løvholt. F. \& Høgestøl, M. 2007: An early Holocene submarine slide in Boknafjorden and the effect of a slide-triggered tsunami on Stone Age settlements at Rennes $\varnothing y$, SW Norway. Marine Geology 243, 157-168. https://doi.org/10.1016/j.margeo.2007.04.015.

Carlson, A.E. \& Clark, P.U. 2012: Ice sheet sources of Sea-level rise and freshwater discharge during the last glaciation. Reviews of Geophysics 50, RG4007. https://doi.org/10.1029/2011RG000371.

Clark, D., McPherson, A., \& van Dissen, R., 2012: Long-term behaviour of Australian stable continental region (SCR) faults. Tectonophysics 566-567, 1-30. https://doi.org/10.1016/j.tecto.2012.07.004.

Clarke, G., Leverington, D., Teller, J. \& Dyke, A. 2003: Superlakes, megafloods, and abrupt climate change. Science 301, 922-923. https://doi.org/10.1126/science.1085921.

Carpenter, G. 1981: Coincident sediment slump/clathrate complexes on the U. S. Atlantic continental slope. Geo-Marine Letters 1, 29-32. https://doi.org/10.1007/BF02463298. 
Cooper, C.L., Swindles G.T., Savov, I.P., Schmidt A. \& Bacon, K.L. 2018: Evaluating the relationship between climate change and volcanism. Earth-Science Reviews 177, 238-247.

https://doi.org/10.1016/j.earscirev.2017.11.009.

Coulson, S., Al-Attar, D. \& Mitrovica, J., 2021: An extended ice-age sea-level equation: incorporating water flux across sills. Geophysical Journal International 225, 236-252.

https://doi.org/10.1093/gji/ggaa596.

Crone, A.J., Machette, M.N. \& Bowman, J.R. 1997: Episodic nature of earthquake activity in stable continental regions revealed by paleoseismicity studies of Australian and North American Quaternary faults. Australian Journal of Earth Sciences 44, 203-214. https://doi.org/10.1080/08120099708728304.

Davies, R.J. 2018: The cause of the 2006 Lusi mud volcano: Please let's not rewrite history. Marine and Petroleum Geology 95, 344. https://doi.org/10.1016/j.marpetgeo.2017.07.013.

Dawson, A., Bondevik, S. \& Teller, J.T. 2011: Relative timing of the Storegga submarine slide, methane release, and climate change during the 8.2.ka cold event. The Holocene 21, 167-171. https://doi.org/10.1177/0959683611400467.

Dawson, A.G. \& Stewart, I. 2007: Tsunami deposits in the geological record. Sedimentary Geology 200, 166-183. https://doi.org/10.1016/j.sedgeo.2007.01.002.

Dehls, J.F., Olesen, O., Olsen, L. \& Blikra, L.H. 2000: Neotectonic faulting in northern Norway; the Stuoragurra and Nordmannvikdalen postglacial faults. Quaternary Science Reviews 19, 1447-1460. https://doi.org/10.1016/S0277-3791(00)00073-1.

De Batist, M., Talling, P., Strasser, M. \& Girardclos, S. 2017: Subaquatic paleoseismology: records of large Holocene earthquakes in marine and lacustrine sediments. Marine Geology 384, 1-3. . https://doi.org/10.1016/j.margeo.2017.04.010.

Doré, A.G., Lundin, E.R., Fichler, C. \& Olesen, O. 1997: Patterns of basement structure and reactivation along the NE Atlantic margin. Journal of the Geological Society of London 154, 85-92. https://doi.org/10.1144/gsjgs.154.1.0085.

Editorial 2013: Quake after-effects. Nature Geoscience 6, 585. https://doi.org/10.1038/ngeo1917.

Eide, E.A., Torsvik, T.H. \& Andersen, T.B. 1997: Absolute dating of brittle fault movements: Late Permian and late Jurassic fault breccias in western Norway. Terra Nova 9, 135-139. https://doi.org/10.1046/j.1365-3121.1997.d01-21.x.

Eldholm, O., Bungum, H., in prep. Earthquakes and climate: enigmas and questions.

Eldholm, O. \& Coffin, M.F. 2000: Large Igneous Provinces and Plate Tectonics. In Richard, M., Gordon, R. \& van der Hilst, R. (eds.): The History and Dynamics of Global Plate Motion, Geophysical Monograph 121, American Geophysical Union, pp. 309-326.

Elmore, A.C., Wright, J.D. \& Southon, J. 2015: Continued meltwater influence on North Atlantic deep water instabilities during the early Holocene. Marine Geology 160, 17-24. https://doi.org/10.1016/j.margeo.2014.11.015. 
Evans, D. \& 13 others 2005: Paleoslides and other mass failures of Pliocene to Pleistocene age along the Atlantic continental margin of NW Europe. Marine and Petroleum Geology 22, 1131-1148. https://doi.org/10.1016/j.marpetgeo.2005.01.010.

Fan, X. \& 14 others 2020: The formation and impact of landslide dams - state of the art. Earth-Science Reviews 203, 103116, https://doi.org/10.1016/j.earscirev.2020.103116.

Fan, W., McGuire, J.J. \& Shearer, P.M. 2020: Abundant spontaneous and dynamically triggered submarine landslides in the Gulf of Mexico. Journal of Geophysical Research 47(12), e2020GL087213, https://doi.org/10.1029/2020GL087213 10 pp.

FENCAT 2020: https://www.seismo.helsinki.fi/bulletin/list/catalog/Scandia_updated.html.

Fenton, C.H. 1994: Postglacial faulting in Eastern Canada. Geological Survey of Canada Open File 2774, $98 \mathrm{pp}$.

Fischer, T.G. 2020: Megaflooding associated with glacial Lake Agassiz. Earth-Science Reviews 201, 102974. https://doi.org/10.1016/j.earscirev.2019.102974.

Fischer, D., Mogillón, J.M., Strasser, M., Pape, T., Bohrmann, G., Fekete, N., Spiess, E. \& Kasten, S. 2013: Subduction zone earthquake as potential trigger of submarine hydrocarbon seepage. Nature Geoscience 6, 647-651. https://doi.org/10.1038/NGEO1886.

Fjeldskaar, W., Lindholm, C., Dehls, J.F. \& Fjeldskaar, I. 2000: Postglacial uplift, neotectonics and seismicity in Fennoscandia. Quaternary Science Reviews 19, 1413-1422. https://doi.org/10.1016/S0277-3791(00)00070-6.

Fleming, K., Johnston, P., Zwarts, D., Yokoyam, Y., Lambeck, K. \& Chapell, J. 1998: Refining the eustatic sealevel curve since the Last Glacial Maximum using far- and intermediate-field sites. Earth and Planetary Science Letters 163, 327-342. https://doi.org/10.1016/S0012-821X(98)00198-8.

Fonseca, J.F.B-D., 2020. A reassessment of the magnitude of the 1755 Lisbon earthquake. Bulletin of the Seismological Society of America 110, 1-17. https://doi.org/10.1785/0120190198.

Franek, P., Plaza-Faverola, A., Mienert, J., Buenz, S., Ferré, B. \& Hubbard, A., 2017: Microseismicity linked to gas migration and leakage on the Western Svalbard shelf. Geochemistry, Geophysics, Geosystems 18, 4623-4645. https://doi.org/10.1002/2017GC007107.

Fruergaard, M., Piasecki, S., Johannessen, P.N., Noe-Nygaard, N., Andersen, T.J., Peirup, M. \& Nielsen, L.H. 2015: Tsunami propagation over a wide, shallow continental shelf caused by the Storegga slide, southeastern North Sea, Denmark. Geology 43, 1047-1050. https://doi.org/10.1130/G37151.1.

Furseth, A. 2012: Farlige Bølger. Vigmostad \& Bjørke, 205 pp.

Fyke, J., Sergienko, O., Löferverström, M., Price, S. \& Lenaerts, J.T.M. 2018: An overview of interactions and feedbacks between ice sheets and the Earth system. Reviews of Geophysics 56, 361-408. https://doi.org/10.1029/2018RG000600. 
Gabrielsen, R.H.,Odinsen, T. \& Grunnaleite, I., 1999: Structuring of the Northern Viking Graben and the Møre Basin; the influence of basement structural grain, and the particular role of the Møre-Trøndelag Fault Complex. Marine and Petroleum Geology 16, 443-465. https://doi.org/10.1016/S0264-8172(99)00006-9.

Gauer, P., Kvalstad, T.J., Forsberg, C.F., Bryn, P. \& Berg, K., 2005: The last phase of the Storegga Slide: simulation of retrogressive slide dynamics and comparison with slide-scar morphology. Marine and Petroleum Geology 22, 171-178. https://doi.org/10.1016/j.marpetgeo.2004.10.004.

Gràcia, E., Lamarche, G., Nelson, H. \& Pantosti, D. 2017: Preface: Marine and lake paleoseismology. Natural Hazards and Earth System Sciences 13, 3469-3478, https://doi.org/10.5194/nhess-13-3469-2013.

Grant, L.B. 2002: Paleoseismology. In Lee, WH.K. et al. (eds.) International Handbook of Earthquake and Engineering Seismology, 475-489.

Gregoire L.J., Payne A. J. \& Valdes P.J. 2012: Deglacial rapid Sea-level rises causes by ice-sheet saddle collapses. Nature 487, 219-222. https://doi.org/10.1038/nature11257.

Goff J., Terry J.P., Chaqué-Goff, C. \& Goto, K. 2014: What is a mega-tsunami? Marine Geology 358, 12-17. https://doi.org/10.1016/j.margeo.2014.03.013.

Haflidason, H., Lien, R., Sejrup, H.P., Forsberg, C.F. \& Bryn, P. 2005: The dating and morphometry of the Storegga Slide. Marine and Petroleum Geology 22, 123-136. https://doi.org/10.1016/j.marpetgeo.2004.10.008.

Handwerger, A.L., Rempel, A.W. \& Skarbek, R.M., 2017: Submarine landslides triggered by destabilization of high-saturation hydrate anomalies. Geochemistry, Geophysics, Geosystems 18, 2429-2445. https://doi.org/10.1002/2016GC006706.

Harbitz, C.B., Glimsdal, S., Løvholt, F., Kveldsvik, V., Pedersen, G.K. \& Jensen, A. 2014: Rockslide tsunamis in complex fjords: From unstable rock slope at Åkerneset to tsunami risk in western Norway. Coastal Engineering 88, 101-122. https://doi.org/10.1016/j.coastaleng.2014.02.003.

Harbitz, C.B, Løvholdt, F. \& Bungum H. 2013: Submarine landslide tsunamis: how extreme and how likely? Natural Hazards 72, 1341-1374. https://doi.org/10.1007/s11069-013-0681-3.

Havskov J. \& Ottemöller L. 2010: Routine data processing in Earthquake Seismology. Springer, 347pp.

Hansen, L., Tassis, G. \& Høgaas, F. 2020: Sand dunes and valley fills from Preboreal glacial-lake outburst floods in southeastern Norway - beyond the aeolian paradigm. Sedimentology 67, 810-848. https://doi.org/10.1111/sed.12663.

Hansen, R.A., Bungum, H. \& Alsaker, A. 1989: Three recent larger earthquakes offshore Norway. Terra Nova 1, 284-295. https://doi.org/10.1111/j.1365-3121.1989.tb00371.x.

He, H., Wei, Z. \& Densmore, A. 2016: Quantitative morphology of bedrock faults and identification of paleo-earthquakes. Tectonophysics 693, 22-31. https://doi.org/10.1016/j.tecto.2016.09.032.

Heimann, M. 2010: How stable is the methane cycle? Science 327, 1211-1212.

https://doi.org/10.1126/science.1187270. 
Henstra, G.A., Berg Kristensen,T. Rotevatn, A. \& Gawthorpe, R.L. 2019: How do pre-existing normal faults influence rift geometry? A comparison of adjacent basins with contrasting underlying structure on the Lofoten Margin, Norway. Basin Research 31, 1083-1098. https://doi.org/10.1111/bre.12358.

Hermanns, R.L. \& 13 others 2013: Hazard and risk classification for large unstable rock slopes in Norway. Italian J. of Engineering Geology and Environment, Book Series 6, 245-254. https://doi.org/10.4408/IJEGE.2013-06.B-22.

Hilger, P., Hermanns, R.L., Gosse, J.C., Jacobs, B., Etzelmüller, B. \& Krautblatter, M. 2018: Multiple rock-slope failures from Mannen in Romsdal Valley, western Norway, revealed from Quaternary geological mapping and 10Be exposure dating. The Holocene 28, 1841-1854. https://doi.org/10.1177/0959683618798165.

Hillman, J. I, T., Crutchley, G. J. \& Kroeger, K. F. 2020: Investigating the role of faults in fluid migration and gas hydrate formation along the Hikurangi Margin, New Zealand. Marine Geophysical Research 41, 8. https://doi.org/10.31223/OSF.IO/BAJ4X.

Hjelstuen, B.O., Eldholm, O. \& Faleide, J.I. 2007: Recurrent Pleistocene mega-failures on the SW Barents Sea Margin. Earth and Planetary Science Letters 258, 605-618.

https://doi.org/10.1016/j.epsl.2007.04.025.

Hjelstuen, B.O., Eldholm, O. \& Skogseid, J. 1999: Cenozoic evolution of the northern Vøring margin. Geological Society of America Bulletin 111, 1792-1807.

https://doi.org/10.1130/0016-7606(1999)111<1792:CEOTNV>2.3.CO;2.

Hjelstuen, B.O., H., Sejrup, H.P., Valvik, E. \& Becker, L.W.M. 2018: Evidence of an ice-dammed lake outburst in the North Sea during the last deglaciation. Marine Geology 402, 118-130.

https://doi.org/10.1016/j.margeo.2017.11.021.

Hjelstuen, B.O., Haflidason, H., Sejrup, H.P. \& Nygård. A. 2010: Sedimentary and structural control on pockmark development - evidence from the Nyegga pockmark field, NW European margin. Geo-Marine Letters 30, 221-230. https://doi.org/10.1007/s00367-009-0172-4.

Hopcroft, P. 2017: Ancient ice and the global methane cycle. Nature, 548, 403.

https://doi.org/10.1038/548403a.

Hovland, M., \& Judd, A.G. 1988: Seabed pockmarks and seepages. Graham \& Trotman, 293 pp.

Huang, R. \& Fan, X. 2013: The landslide story. Nature Geoscience 6, 325-326.

https://doi.org/10.1038/ngeo1806.

Hughes, A.L.C., Gyllencreutz, R., Lohne, Ø.S., Mangerud, J. \& Svendsen, J.I. 2015: The last Eurasian Ice Sheets - a chronological database and time-slice reconstruction, DATED-1. Boreas 45(1), 1-45. https://doi.org/10.1111/bor.12142.

Hustoft, S., Dugan, B. \& Mienert, J. 2009: Effects of rapid sedimentation on developing the Nyegga pockmark field: constraints from hydrological modeling and 3-D seismic data, offshore mid-Norway. Geochemistry, Geophysics, Geosystems 10, Q0612. https://doi.org/10.1029/2009GC002409.

Hutri, K-L., Heinsalu, A., Kotilainen, A.T. \& Ojala, A.E.K. 2007: Dating early Holocene paleoseismic event(s) in the Gulf of Bothnia, Baltic Sea. Boreas 36, 56-64. https://doi.org/10.1111/j.1502-3885.2007.tb01180.x. 
Hutri, K-L. \& Kotilainen, A. 2007: An acoustic view into Holocene paleoseismicity offshore southwestern Finland, Baltic Sea. Marine Geology 238, 45-59. https://doi.org/10.1016/j.margeo.2006.12.006.

Høgaas, F. \& Longva, O. 2016: Mega deposits and erosive features related to the glacial lake Nedre Glomsjø outburst flood, southeastern Norway. Quaternary Science Reviews 151, 273-291. https://doi.org/10.1016/j.quascirev.2016.09.015.

Høgaas, F. \& Longva, O. 2018: The early Holocene ice-dammed lake Nedre Glomsjø: an open lake system succeeding an actively retreating ice sheet. Norwegian Journal of Geology 98, 661-675. https://dx.doi.org/10.17850/njg98-4-08.

Høgaas, F., Longva, O., Hansen, L. \& Olsen, L. 2017: Mega deposits and erosive features related to the glacial lake Nedre Glomsjø outburst flood (abs.). Norsk Geologisk Forening, Abstract Proceedings No 1 , p 41.

Jakobsson, M., Björck, S., Alm, G., Andrén, T., Lindeberg, G. \& Svensson, N.-O. 2007: Reconstructing the Younger Dryas ice dammed lake in the Baltic Basin: Bathymetry, area and volume. Global Planetary Change 57, 355-370. https://doi.org/10.1016/j.gloplacha.2007.01.006.

Jakobsson, M., Björck, S., O’Regan, M., Flodén, T., Greenwood, S.L., Swärd, H., Lif, A., Ampel, L., Koyi, H. \& Skelton, A. 2014: Major earthquake at the Pleistocene-Holocene transition in Lake Vättern, southern Sweden. Geology 42, 379-382. https://doi.org/10.1130/G35499.1.

Jibson, R.W. 1996: Using landslides for paleoseismic analysis. In McCalpin J.P. (ed.): Paleoseismology, Academic Press Inc., San Diego, California, 397-438.

Johnson, H.P., Gomberg, J.S., Hautala, S.L. \& Salmi, M.S. 2017: Sediment gravity flows triggered by remotely generated earthquake waves. Journal of Geophysical Research 122, 4584-4600. https://doi.org/10.1002/2016JB013689.

Johnston, A.C. 1996: A wave in the Earth. Science 274, 735.

https://doi.org/10.1126/science.274.5288.735.

Johnston, A.C. \& Kanter, L.R. 1990: Earthquakes in stable continental crust. Scientific American 262, 68-75. https://doi.org/10.1038/scientificamerican0390-68.

Johnston, A.C., Coppersmith, K.J., Kanter, L.R. \& Cornell, C.A. 1994: The earthquakes of stable continental regions. Technical Report EPRI-TR-102261s-V1-V5, Electric Power Research Institute, Palo Alto, CA.

Jolly, A.D. 2019: On the shallow volcanic response to remote seismicity. Geology 47, 95-96. https://doi.org/10.1130/focus012019.1.

Juhlin, C., Dehghannejad, M., Lund, B.A., Malehmir, A. \& Pratt, G. 2010: Reflection seismic imaging of the end-glacial Pärvie Fault system, northern Sweden. Journal of Applied Geophysics 70, 307-316. https://doi.org/10.1016/j.jappgeo.2009.06.004.

Jørstad, F.A. 1968: Waves generated by landslides in Norwegian fjords and lakes. Norwegian Geotechnical Institute, Publ. No 79, 20 pp. 
Karstens, J., Haflidason, H., Becker, L.B.M., Berndt, C., Rüpke, L., Planke, S., Liebetrau, V., Schmidt, M. \& Mienert, J. 2018: Glacigenic sedimentation pulses triggered post-glacial gas hydrate dissociation. Nature Communications 9, 635. https://doi.org/10.1038/s41467-018-03043-z.

Kendall, R.A., Mitrovica, J.X., Milne, G.A., Tornquist, T.E. \& Li, Y. 2008: The sea-level fingerprint of the 8.2 ka climate event. Geology 36, 423-426. https://doi.org/10.1130/G24550A.1.

Keiding, M., Kreemer, C., Lindholm, C.D., Gradmann, S., Olesen, O. \& Kierulf, H.P. 2015: A comparison of strain rates and seismicity for Fennoscandia: depth dependency of deformation from glacial isostatic adjustment. Geophysical Journal International 202, 1021-1028. https://doi.org/10.1093/gji/ggv207.

Keisling, B.A., Nielsen, L.T., Hvidberg, C.S., Nuterman, R. \& DeConto, D.C. 2020: Pliocene-Pleistocene megafloods as a mechanism for Greenlandic megacanyon formation. Geology 48, 737-741. https://doi.org/10.1130/G47253.1.

Kierulf, H.P., Ouassou, M., Simpson, M.J.R. \& Vestøl, O. 2014: A continuous velocity field for Norway. Journal of Geodesy 87, 337-349. https://doi.org/10.1007/s00190-012-0603-2.

Kinoshita, C., Saffer, D.M., 2018. In situ permeability and scale dependence of an active accretionary prism determined from cross-borehole experiments. Geophysical Research Letters 45, 6935-6943.

https://doi.org/10.1029/2018GL078304.

Kolderup, C.F. 1913: Norges jordskjælv med særlig hensyn til deres utbredelse i rum og tid [Earthquakes in Norway with specific attention to their occurrence in space and time]. Bergen Museums Aarbog 8 [in Norwegian with German abstract]

Korup, O., 2012: Earth's portfolio of extreme sediment transport events. Earth Science Reviews 112, 115-125. https://doi.org/10.1016/j.earscirev.2012.02.006.

Kotilainen, A. \& Hutri, K-L. 2004: Submarine Holocene sedimentary disturbances in the Olkiluoto area of the Gulf of Bothnia, Baltic Sea: a case of postglacial paleoseismicity. Quaternary Science Reviews 23, 1125-1135. https://doi.org/10.1016/j.quascirev.2003.12.002.

Kremer, K., Wirth, S.B., Reusch, A., Fäh, D., Bellwald, B., Ansemetti, F.S. Giradclos, S \& Strasser, M. 2017 : Lake-sediment based paleoseismology: Limitations and perspectives from the Swiss Alps. Quaternary Science Reviews 168, 1-18. https://doi.org/10.1016/j.quascirev.2017.04.026.

Kujansuu, R., 1964: Nuorista siirroksista Lapissa (Recent faults in Lapland). Geologi 16, 30-36.

Kukkonen, I.T., Ask, M.V.S. \& Olesen, O., 2011: Postglacial fault drilling in northern Europe: Workshop in Skokloster, Sweden. Scientific Drilling No 11, 56-59. https://doi.org/10.2204/iodp.sd.11.08.2011.

Kukkonen, I.T., Olesen, O., Ask, M.V.S. \& PFDP Working Group 2010: Postglacial faults in Fennoscandia: targets for scientific drilling. Geologiska Föreningen i Stockholm Förhandlingar 132, 71-81.

https://doi.org/10.1080/11035891003692934.

Kvale, A. 1955: Seismic seiches in Norway and England during the Assam earthquake of August 15, 1950. Bulletin of the Seismological Society of America 45, 93-113.

Kvalstad, T.J., Andresen, L., Forsberg, C.F., Berg, K., Bryn, P. \& Wangen, M. 2005: The Storegga slide: evaluation of triggering sources and slide mechanisms. Marine and Petroleum Geology 22, $245-256$. https://doi.org/10.1016/j.marpetgeo.2004.10.019. 
Kvenvolden, K.A. 1993: Gas hydrates - Geological perspective and global change. Reviews of Geophysics 31, 173-187. https://doi.org/10.1029/93RG00268.

Lagerbäck, R. \& Sundh, M. 2008: Early Holocene faulting and paleoseismicity in northern Sweden. Geological Survey of Sweden, Research Paper C 836, 80pp.

Lagerbäck, R., 1979: Neotectonic structures in Northern Sweden. Geologiska Föreningen i Stockholm Förhandlingar 100, 263-269. https://doi.org/10.1080/11035897809452533.

Lane, T.P. \& 9 others 2020: Elevation changes of the Fennoscandian ice sheet interior during the last glaciation. Geophysical Research Letters 47, e2020GL088796, https://doi.org/10.1029/2020GL088796.

Lee, H.J., 2009: Timing of occurrence of large submarine landslides on the Atlantic Ocean margin. Marine Geology 264, 53-64. https://doi.org/10.1016/j.margeo.2008.09.009.

Leonard, M. \& Clark, D. 2011: A record of stable continental earthquakes from Western Australia spanning the late Pleistocene: Insights for contemporary seismicity. Earth and Planetary Science Letters 309, 207-212. https://doi.org/10.1016/j.epsl.2011.06.035.

Leynaud, D., Mienert, J. \& Vanneste, M., 2009: Submarine mass movements on glaciated and non-glaciated margins: A review of triggering mechanisms and precondition to failure. Marine and Petroleum Geology 26, 618-632. https://doi.org/10.1016/j.marpetgeo.2008.02.008.

Li, T., Wu, P., Wang, H., Steffen, H., Khan, N.S., Engelhart, S.E., Vacchi, M., Shaw, T.A., Peltier, W.R. \& Horton, B.P. 2020: Uncertainties of Glacial Isostatic Adjustment. Model predictions in North America associated with 3D structure. Geophysical Research Letters 47, e2020GL087944. https://doi.org/10.1029/2020GL087944.

Lindblom, E., Lund, B., Tryggvason, A., Uski, M., Bödvarsson, R., Juhlin, C. \& Roberts, R. 2015: Microearthquakes illuminate the deep structure of the endglacial Pärvie Fault, northern Sweden. Geophysical Journal International 201, 1704-1716. https://doi.org/10.1093/gji/ggv112.

Lindholm, C. 2019: Jordskjelv i Norge/Earthquakes in Norway. Fjellsprengningsdagen, Oslo, 21 November, 2019. Norsk forening for fjellsprengningsteknikk, Norsk Bergmekanikkgruppe \& Norsk Geoteknisk Forening, p. 8.1-8.13. Downloadable from https://nff.no/publikasjoner/fjellsprengningsdagen/.

Lindholm, C., Roth, M., Bungum \& H. \& Faleide, J.I. 2005: Probabilistic and deterministic seismic hazard results and influence of the sedimentary Møre Basin., NE Atlantic. Marine and Petroleum Geology 22, 149-160. https://doi.org/10.1016/j.marpetgeo.2004.10.006.

Lindqvist, J. 2010: Deposits from landslides and avalanches triggered by seismic activity in Swedish Lapland. Geografiska Annaler, Series A. 92, 411-420.

https://doi.org/10.1111/j.1468-0459.2010.00404.x.

Lippold, J. \& 10 others 2019: Constraining the variability of the Atlantic Meridional Overturning Circulation during the Holocene, Geophysical Research Letters 46, 11338-11346. https://doi.org/10.1029/2019GL084988.

Llopart, J. \& 8 others 2019: Fluid flow and pore pressure development throughout the evolution of a trough mouth fan, western Barents Sea. Basin Research 31, 487-513.

https://doi.org/10.1111/bre.12331. 
Long, A.J., Roberts, D.H. \& Dawson, S. 2006: Early Holocene history of the west Greenland ice sheet and the GH-8.2 event. Quaternary Science Reviews 25, 904-922.

https://doi.org/10.1016/j.quascirev.2005.07.002.

Longva, O. 1994: Flood Deposits and Erosional Features from the Catastrophic Drainage of Preboreal Glacial Lake Nedre Glåmsjø, SE Norway. PhD thesis, University of Bergen, Department of Geology.

Longva, O., Blikra. L.H. \& Dehls. J.F. 2009: Rock avalanches - distribution and frequencies in the inner part of Storfjorden, Møre og Romsdal County, Norway. Norwegian Geological Survey, Report No 2009.002, $32 \mathrm{pp}$.

Lund, B., Roberts, R \& Smith, C.A, 2017: Review of paleo-, historical and current seismicity in Sweden and surrounding areas with implications for the seismic analysis underlying SKI report 92:3. Swedish Radiation Safety Authority (SSM) Report 2017:35. Downloadable from https://www.stralsakerhetsmyndigheten.se/publikationer/.

Lund, B., Schmidt, P. \& Hieronymus, C. 2009: Stress evolution and fault stability during the Weichselian glcial cycle. Swedish Nuclear Fuel and Waste Management Co., Technical Report TR-09-15, 106 pp.

Lupi, M., Saenger, E.H., Fuchs, E. \& Miller, S.A. 2013: Lusi mud eruption triggered by geometric focusing of seismic waves. Nature Geosciences 6, 642-646. https://doi.org/10.1038/ngeo1884.

Løvholt, F., Bondevik, S., Laberg, J.S., Kim, J. \& Boylan, J. 2017: Some giant submarine landslides do not produce large tsunamis. Geophysical Research Letters 44, 8463-8472.

https://doi.org/10.1002/2017GL074062.

Løvholt, F., Schulten, I., Mosher, D., Harbitz, D. \& Krastel, S. 2018: Modelling the 1929 Grand Banks slump and landslide tsunami. Geological Society, London, Special Publications 477, 315-331.

https://doi.org/10.1144/SP477.28.

Lyså, A., Hjelstuen, B.O. \& Larsen, E. 2009: Fjord infill in a high-relief area: Rapid deposition influenced by deglaciation dynamics, glasio-isostatic rebound and gravitational activity. Boreas 39, 39-55.

https://doi.org/10.1111/j.1502-3885.2009.00117.x.

Maestrelli, D., Bonini, M., Donne, D.D., Manga, M., Piccardi, L. \& Sani, F., 2017: Dynamic triggering of mud volcano eruptions during the 2016-2017 central Italy seismic sequence. J. Geophys. Res. Solid Earth, 122, 9149-9165. https://doi.org/10.1002/2017JB014777.

Malehmir, A. \& 11 others 2016: Poet-glacial reactivation of the Bollnäs fault, central Sweden a multidisciplinary investigation. Solid Earth 7, 509-527. https://doi.org/10.5194/se-7-509-2016.

Malinverno, A, Cook, A.E., Daigle, H. \& Oryan, B. 2018: Glacial cycles influence marine methane hydrate formation. Geophysical Research Letters 45, 724-732. https://doi.org/10.1002/2017GL075848.

Malvoisin, B., Mazzini, A. \& Miller, S.A., 2018: Deep hydrothermal activity driving the Lusi mud eruption. Earth and Planetary Science Letters 497, 42-49. https://doi.org/10.1016/j.epsl.2018.06.006.

Manga, M., Brumm, M., \& Rudolph, M.I., 2009: Earthquake triggering of mud volcanoes. Marine and Petroleum Geology 26, 1785-1798. https://doi.org/10.1016/j.marpetgeo.2009.01.019. 
Mangerud, J. \& 8 others 2018: The timing of deglaciation and sequence of pioneer vegetation at Ringsaker, eastern Norway - and an earthquake-triggered landslide. Norwegian Journal of Geology 98, 301-318. https://dx.doi.org/10.17850/njg98-3-03.

Mäntyniemi, P.B., Sørensen, M.B., Tatevossian, T.N., Tatevossian, R.E. \& Lund, B. 2020: A reappraisal of the Lurøy, Norway, Earthquake of 31 August 1819. Seismological Research Letters 93, 1-11. https://doi.org/10.1785/0220190363.

Matero, I.S.O., Gregoire, L.J., Ivanovic, R.F., Tindall, J.C. \& Haywood, A.M. 2017: The 8.2 ka cooling event caused by Laurentide ice saddle collapse. Earth and Planetary Science Letters 473, 205-214. https://doi.org/10.1016/j.epsl.2017.06.011.

Mattila, J., Ojala, A.E.K., Ruskeneeiemi, T., Palmu, J-P., Aaltonen, I., Käpyaho, S., Lindberg, A. \& Sutinen, R. 2019: Evidence of multiple slip events on postglacial faults in northern Fennoscandia. Quaternary Science Reviews 215, 242-252. https://doi.org/10.1016/j.quascirev.2019.05.022.

Mazzini, A., Svensen, H.N., Forsberg, C.F., Linge, H., Lauritzen, S-E., Haflidason, H., Hammer, $\varnothing$., Planke, S. \& Tjelta, T.I. 2017: A climatic trigger for the giant Troll pockmark field in the northern North Sea. Earth and Planetary Science Letters 464, 24-34. https://doi.org/10.1016/j.epsl.2017.02.014.

McCalpin, J.P. \& Nelson, A.R. 1996: Introduction to Paleoseismology. In McCalpin J.P. (ed.): Paleoseismology, Academic Press Inc., San Diego, California, 1-32.

McGarr A. 1965: Excitation of seiches in channels by seismic waves. Journal of Geophysical Research 70, 847-854. https://doi.org/10.1029/JZ070i004p00847.

McGarr A. \& Vorhis R.C. 1968: Seismic seiches from the March 1964 Alaska earthquake. U.S. Geological Survey, Professional Paper 544, E1-E43.

Mienert J., Vanneste M., Bünz S., Andreasssen K., Haflidason H. \& Sejrup H.P. 2005: Ocean warming and gas hydrate stability on the mid-Norwegian margin at the Storegga Slide. Marine and Petroleum Geology 22, 233-244. https://doi.org/10.1016/j.marpetgeo.2004.10.018.

Mienert, J., Posevang, J. \& Lukas, D., 2001: Changes in the hydrate stability zone on the Norwegian margin and their consequences for methane and carbon release into the oceanosphere. In Schafer, P., Ritsrau, E., Schlüter, M. \& Thiede, J. (eds.): The Northern North Atlantic: A changing environment. Springer, Berlin, 259-280.

Mikko, H., Smith, C.A. Lund, B., Ask, M.V.S. \& Munier, R., 2015: LIDAR-derived inventory of post-glacial fault scarps in Sweden. Geologiska Föreningen i Stockholm Förhandlingar 137, 338-344. https://doi.org/10.1080/11035897.2015.1036360.

Mrope, F.M., Becken, M., Ruud, B.O., Olesen, O., Johansen, T.A., Brönner, M., Gradmann, S. \& Nasuti, A. 2019: Magnetotelluric 2D inversion and joint interpretation MT, seismic, magnetic, and gravity data from Masi, Kautokeino municipality, Finnmark. Geological Survey of Norway, Report 2019.009, 64 pp.

Munier, R. \& 26 others, 2020: International database of Glacially Induced Faults. PANGAEA, https://doi.org/10.1594/PANGAEA.922705.

Muir Wood, R. 1988: The Scandinavian earthquakes of 22 December 1759 and 31 August 1819. Disasters 12, 223-236. https://doi.org/10.1111/j.1467-7717.1988.tb00672.x. 
Muir Wood, R. 1989: Extraordinary deglaciation reverse faulting in northern Fennoscandia. In Gregersen, S. \& Basham, P.W. (eds.): Earthquakes at North-Atlantic passive margins: neotectonics and postglacial rebound. Kluwer, Dordrecht, 141-173.

Muir Wood, R. 1993: A review of the seismotectonics of Sweden. Swedish Nuclear Fuel and Waste Management Co. (SKB) Technical Report 93-13, 225 pp.

Muir Wood, R. 2000: Deglaciation seismotectonics: a principal influence on intraplate seismogenesis at high latitudes. Quaternary Science Reviews 19, 1399-1411.

https://doi.org/10.1016/S0277-3791(00)00069-X.

Muir Wood, R. \& King, G.C.P. 1993: Hydrological signatures of earthquake strain. Journal of Geophysical Research 98, 22,035-22,068. https://doi.org/10.1029/93JB02219.

Muir Wood, R. \& Woo, G., 1987: The historical seismicity of the Norwegian continental shelf. ELOCS - Earthquake Loading on the Norwegian Continental Shelf. NORSAR and Norwegian Geotechnical Institute, Report 2-1, 60 pp.

Mörner N.-A. 1985: Paleoseismicity and geodynamics in Sweden. Tectonophysics 117, 139-153. https://doi.org/10.1016/0040-1951(85)90242-2.

Mörner, N-A. 1996: Liquefaction and varve deformation as evidence of paleoseismic events and tsunamis. The autumn 10,430 BP case in Sweden. Quaternary Science Reviews 15, 939-948. https://doi.org/10.1016/S0277-3791(96)00057-1.

Mörner, N.-A. 2005: An interpretation and catalogue of paleoseismicity in Sweden. Tectonophysics 408, 265-307. https://doi.org/10.1016/j.tecto.2005.05.039.

Mörner, N.-A. 2009: Late Holocene earthquake geology in Sweden. Geological Society, London, Special Publications 316, 179-188. https://doi.org/10.1144/SP316.11.

Mörner, N-A. 2017: Methane hydrate in crystalline bedrock and explosive venting tectonics. Earth-Science Review 169, 202-212. https://doi.org/10.1016/j.earscirev.2017.05.003.

Namiki, A., Rivalta, E., Woith, H., Willey, T., Parolai, S. \& Walter, T.R. 2018: Volcanic activities triggered or inhibited by resonance of volcanic edifices to large earthquakes. Geology 47, 67-70. https://doi.org/10.1130/G45323.1.

Nansen, F. 1922: The Strandflat and Isostacy. Videnskapselskapets Skrifter. Matematisknaturvitenskapelig Klasse, No. 11, 313 pp.

Nikolaeva, S.B., Nikonov, A.A. \& Shvarev, S.V. in press: Late glacial and postglacial faulting in the Russian part of the Fennoscandian Shield. In Steffen, H., Olesen, O. \& Sutinen, R. (eds.): Glacially-Triggered Faulting, Cambridge University Press.

Normandeau, A., Campell, D.C., Piper, D.J.W. \& Jenner, K.A., 2019: Are submarine landslides an underestimated hazard on the western North Atlantic passive margin? Geology 47, 848-852. https://doi.org/10.1130/G46201.1.

NPD (Norwegian Petroleum Directorate) 2020: Structural elements on the Norwegian Continental Shelf, https://www.npd.no/en/facts/geology/structure-elements/. 
Nur, A. 2002: Earthquakes and archaeology. In Lee W.H.K. et al. (eds.): International Handbook of Earthquake and Engineering Seismology, 765-774. Academic Press, Amsterdam.

Ojala, A.E.K., Mattila, J., Hämäläinen, J. \& Sutinen, R., 2019: Lake sediment evidence of paleoseismicity: Timing and spatial occurrence of late- and postglacial earthquakes in Finland. Tectonophysics 771, 228227. https://doi.org/10.1016/j.tecto.2019.228227.

Ojala, A.E.K., Markovaara-Koivisto. M., Middleton, M., Ruskeeniemu, T., Mattila, J. \& Sutinen, R. 2018a: Dating of paleolandslides in western Finnish Lapland. Earth Surface Processes and Landforms 43, 2449-2462. https://doi.org/10.1002/esp.4408.

Ojala, A.E.K., Mattila, J., Markovaara-Koivisto, M., Ruskeeniemi, T., Palmu, J-P. \& Sutinen, R. 2017a: Distribution and morphology in northern Finland: An analysis of postglacial activity. Geomorphology 326, 190-201. https://doi.org/10.1016/j.geomorph.2017.08.045.

Ojala, A.E.K. Mattila, J., Virtasaloa, J., Kuvaa, J. \& Luoto, T.P. 2018b: Seismic deformation of varved sediments in southern Fennoscandia at $7400 \mathrm{cal}$ BP. Tectonophysics 744, 58-71. https://doi.org/10.1016/j.tecto.2018.06.015.

Ojala, A.E.K., Mattila, J., Ruskeniemi, T., Palmu, J-P., Lindberg, A., Hänninen P. \& Sutinen, R. 2017b: Postglacial seismic activity along the Isovaara-Riikonkumpu fault complex. Global Planetary Change 157, 59-72. https://doi.org/10.1016/j.gloplacha.2017.08.015.

Olesen, O. 1988: The Stuoragurra Fault, evidence of neotectonics in the Precambrian of Finnmark, northern Norway. Norwegian Journal of Geology 68, 107-118.

Olesen, O. \& 9 others 2004: Neotectonic deformation in Norway and its implications: A review. Norwegian Journal of Geology 84, 3-34.

Olesen, O., Bungum, H., Dehls, J., Lindholm, C., Pascal, C. \& Roberts, D. 2013: Neotectonics, seismicity and contemporary stress field in Norway - mechanisms and implications. Geological Survey of Norway, Special Publication 13, 145-174.

Olesen, O. \& Lindholm, C. 2019: 200 år siden “Lurøyskjelvet”. GEO, Sept. 2019, 22-28. https://www.geoforskning.no/nyheter/geofarer/2100-200-ar-siden-luroyskjelvet.

Olesen, O., Olsen, L., Gibbons, S.J., Ruud, B.O., Høgaas, F., Johansen, T.A. \& Kværna, T., in press. Postglacial faulting in Norway - Large magnitude earthquakes of the Late Holocene age. In Steffen, H., Olesen, O. \& Sutinen, R. (eds.): Glacially-triggered Faulting, Cambridge University Press.

Olsen, L., Olesen, O., Dehls, J \& Tassis, G. 2018: Late-/postglacial age and tectonic origin of the Nordmannvikdalen Fault, northern Norway. Norwegian Journal of Geology 98, 483-500. https://dx.doi.org/10.17850/njg98-3-09.

Olsen, L. \& Høgaas, F. 2020: "Shaken, not stirred": Mosaic sand - a semi-liquefaction phenomenon originating from strong earthquakes. NGU Report 2020.020, 32 pp. https://www.ngu.no/upload/Publikasjoner/Rapporter/2020/2020_020.pdf.

Olsen, E., Gabrielsen, R.H., Braathen, A. \& Redfield, T.F. 2007: Fault systems marginal to the MøreTrøndelag Fault Complex, Osen -Vikna area, Central Norway. Norwegian Journal of Geology 87, 59-73. 
Olsen, L., Olesen, O. \& Høgaas, F. 2020: Dating of the Stuoragurra Fault at Finnmarksvidda, northern Norway (abs.). Geological Society of Norway, Abstract Proceedings No 1.

Osmundsen, P.T., Péron-Pinvidic,G. \& Bunkholt, H. 2021: Rifting of collapsed orogens: Successive incision of continental crust in the proximal margin offshore Norway. Tectonics 40. https://doi.org/10.1029/2020TC006283.

Palmu, J-P., Ojala, A.E.K., Ruskeeniemi, T., Sutinen, R. \& Mattila, J. 2015: LIDAR DEM detection and classification of post-glacial faults and seismically-induced landforms in Finland: a paleoseismic database. Geologiska Föreningen i Stockholm Förhandlingar 137, 344-352.

https://doi.org/10.1080/11035897.2015.1068370.

Peltier, W.R., 2004. Global glacial isostacy and the surface of the Ice-Age Earth; the ICE-5G (VM2) model and GRACE. Annual Review of Earth and Planetary Sciences 32, 111-149.

https://doi.org/10.1146/annurev.earth.32.082503.144359.

Peltier, W.R., Argus, D.F. \& Drummond, R. 2015: Space geodesy constrains ice age terminal deglaciation: The global ICE-6G_C (VM5a) model. Journal of Geophysical Research 120, 450-487. https://doi.org/10.1002/2014JB011176.

Phillips, T.B., Fazlikani, H., Gawthorpe, R.L., Fossen, H., Jackson, C.A.L., Bell, R.E., Faleide, J.I. \& Rotevatn, A. 2019: The influence of structural inheritance and multiphase extension of rift development, the Northern North Sea. Tectonics 38, 4099-4126. https://doi.org/10.1029/2019TC005756.

Piccardi, L. \& Masse, W.B. (eds.) 2007: Myth and Geology. Geological Society, London, Special Publication 273, 360 pp. https://doi.org/10.1016/j.quascirev.2008.06.002.

Pirli, M. \& 11 others 2010: Preliminary analysis of the 21 February 2008 Svalbard (Norway) seismic sequence. Seismological Research Letters 81, 63-75. https://doi.org/10.1785/gssrl.81.1.63.

Polonia, A., Romano, S., Çağatay, M.N., Capotondi, L., Gasparetto, G., Gasperini, L., Panieri, G. \& Torelli, L. 2015: Are repetitive slumpings during sapropel S1 related to paleo-earthquakes? Marine Geology 361, 41-52. https://doi.org/10.1016/j.margeo.2015.01.001.

Pope, E.L., Talling, P.J., Urlaub, M., Hunt, J.E., Clare, M.A. \& Challenor, P. 2015: Are large submarine landslides temporally random or do uncertainties in available age constraints make it impossible to tell? Marine Geology 369, 19-33. https://doi.org/10.1016/j.margeo.2015.07.002.

Posiva 2019: Postglacial faults in Finland - a review of PGSdyn project results. Posiva Report 2019-1, 118 pp, Posiva OY, Oikiluoto, Finland.

Rasmussen, S.O. \& 15 others 2006: A new Greenland ice core chronology for the last glacial termination. Journal of Geophysical Research 111, D06102. https://doi.org/10.1029/2005JD006079.

Ratzov, G., Cattaneo, A., Babonneau, N., Déverchère, J., Yelles, K., Bracene, R. \& Courbolex, F. 2015: Holocene turbidites record earthquake supercycles at a slow-rate plate boundary. Geology 43, 331-334. https://doi.org/10.1130/G36170.1.

Redfield, T.F. \& Hermanns, R.L. 2016: Gravitational slope deformation, not neotectonics: Revisiting the Nordmannvikdalen feature of northern Norway. Norwegian Journal of Geology 96, 245-273. http://dx.doi.org/10.17850/njg96-3-05. 
Regnéll, C., Mangerud, J. \& Svendsen, J.I. 2020: Tracing the final deglaciation of the Scandinavian Ice Sheet - ice dammed lakes and a catastrophic flood (abs.). Geological Society of Norway, Abstract Proceedings No 1, p 176.

Ren, X., Guo, Z., Ning, F. \& Ma, S. 2020: Permeability of hydrate-bearing sediments. Earth-Science Reviews 202, 103100. https://doi.org/10.1016/j.earscirev.2020.103100.

Reusch, A., Moernaut, J., Anselmetti, F.S. \& Strasser, M. 2016: Sediment mobilization deposits from episodic subsurface fluid flow - A new tool to reveal long-term earthquake records. Geology 44, 243-246. https://doi.org/10.1130/G37410.1.

Romundset, A. \& Bondevik, S., 2010: The first radiocarbon dated sea-level curves from northernmost Norway. Geological Society of Norway, Abstract Proceedings No 1, pp. 161-164.

Ruppel, C.D. \& Kessler, J.D. 2017: The interaction of climate change and methane hydrates. Reviews of Geophysics 55, 126-168. https://doi.org/10.1002/2016RG000534.

Rüther, C., Bjarnadóttir, L.R., Juntilla, J., Husum, K., Rsamussen, T.L., Kucchi, R.G. \& Andreassen, K., 2012: Pattern and timing of the northwestern Barents Sea Ice Sheet deglaciation and indications of episodic Holocene deposition. Boreas 41, 494-512. https://doi.org/10.1111/j.1502-3885.2011.00244.x.

Rydgren, K. \& Bondevik, S. 2015: Moss growth patterns and timing of human exposure to a Mesolithic tsunami in the North Atlantic. Geology 43, 111-114. https://doi.org/10.1130/G36278.1.

Sawi, T.M. \& Manga, M., 2018: Revisiting short-term earthquake triggered volcanism. Bulletin of Volcanology 80, 57. https://doi.org/10.1007/s00445-018-1232-2.

Schulte, S.M. \& Mooney, W.D. 2005: An updated global earthquake catalogue for stable continental regions: reassessing the correlation with ancient rifts. Geophysical Journal International 161, 707-721. https://doi.org/10.1111/j.1365-246X.2005.02554.x.

Schwartz, D.P. 1987: Earthquakes of the Holocene. Reviews of Geophysics 25, 1197-1202. https://doi.org/10.1029/RG025i006p01197.

Screaton, E.J. \& 9 others 2019: Sedimentation controls on methane-hydrate dynamics across glacial interglacial stages: An example from International Ocean Discovery Program U1517, Hikurangi Margin. Geochemistry, Geophysics, Geosystems 20, 4906-4921. https://doi.org/10.1029/2019GC008603.

Shenghua, L., Youli, L., Yiran, W. \& Hongjuan, C. 2014: The Holocene Paleoseismicity of the north Zhongtiaoshan faults in Shanxi Province, China. Tectonophysics 623, 67-82. https://doi.org/10.1016/j.tecto.2014.03.019.

Siegel, J., Lizarralde, D., Dugan, B. \& Person M. 2014: Glacially generated overpressure on the New England continental shelf: Integration of full-waveform inversion and overpressure modeling. Journal of Geophysical Research 119, 3393-3409. https://doi.org/10.1002/2013JB010278.

Siegert, M.J., Dowdeswell, J.A., Hald, M. \& Svendsen, J.I, 2001: Modelling the Eurasian Ice Sheet through a full (Weichselian) glacial cycle. Global Planetary Change 31, 367-385.

https://doi.org/10.1016/S0921-8181(01)00130-8. 
Slunga, R.S. 1991: The Baltic Shield earthquakes. Tectonophysics 189, 323-331.

https://doi.org/10.1016/0040-1951(91)90505-M.

Smith, C.A., Grigull, S. \& Mikko, H. 2018: Geomorphic evidence of multiple surface ruptures of the Merasjärvi "postglacial fault", northern Sweden, Geologiska Föreningen i Stockholm Förhandlingar 140, 318-322. https://doi.org/10.1080/11035897.2018.1492963.

Smith, C.A., Mikko, H. \& Grigull, S. in press: Glacially-induced faults in Sweden: The rise and reassessment of the single-rupture hypothesis. In Steffen, H., Olesen, O. \& Sutinen, R. (eds.): Glacially-triggered Faulting, Cambridge University Press.

Smith, C.A., Sundh, M., \& Mikko, H., 2014: Surficial geology indicates early Holocene faulting and seismicity, central Sweden. International Journal of Earth Sciences 103, 1711-1724. https://doi.org/10.1007/s00531-014-1025-6.

Solheim, A., Bryn, P., Berg, K., Sejrup, H.P. \& Mienert, J. 2005a: Ormen Lange: An integrated study for the safe development of a deep-water gas field within the Storegga Slide Complex, NE Atlantic continental margin. Thematic Volume. Marine and Petroleum Geology 22, 1-9. https://doi.org/10.1016/j.marpetgeo.2004.10.001.

Solheim, A., Berg, K., Forsberg, C.F. \& Bryn, P. 2005b: The Storegga slide complex: repetitive large scale sliding with similar cause and development. Marine and Petroleum Geology 22, 97-107. , https://doi.org/10.1016/j.marpetgeo.2004.10.013.

Steffen, H., Olesen, O., Sutinen, R. (eds.) in press: Glacially-Triggered Faulting. Cambridge Univ. Press.

St-Onge, G. \& 13 others 2012: Comparison of earthquake-triggered turbidite from the Saguenay (EasternCanada)andReloncavi(Chileanmargin)Fjords:Implicationsforpaleoseismicityandsedimentology. Sedimentary Geology 243-244, 89-107. https://doi.org/10.1016/j.sedgeo.2011.11.003.

Strasser, M., Monecke, K., Schnellmann, M. \& Anselmett, F.S. 2013: Lake sediments as natural seismographs: A compiled record of Late Quaternary earthquakes in Central Switzerland and its implication for Alpine deformation. Sedimentology 60, 319-341. https://doi.org/10.1111/sed.12003.

Sutinen, R., Hyvönen, E., Middleton, M. \& Airo, M-L., 2018: Earth-induced deformations on ice-stream landforms in Kuusamo eastern Finnish Lapland. Global Planetary Change 160, 46-60. https://doi.org/10.1016/j.gloplacha.2017.11.011.

Sutinen, R., Hyvönen, E., Middleton, M. \& Ruskeeniemi, T. 2014: Airborne LiDAR detection of postglacial faults and Pulju moraine in Palojärvi, Finnish Lapland. Global and Planetary Change 115, 24-32. https://doi.org/10.1016/j.gloplacha.2014.01.007.

Swafford, L. \& Stein, S. 2007: Limitations of the short earthquake record for seismicity and seismic hazard studies. Geological Society of America Special Publications 425, 49-58.

https://doi.org/10.1130/2007.2425(04).

Swärd, H. \& 10 others 2015: Regional deglaciation and postglacial lake development as reflected in a 74 m sedimentary record from Lake Vattern, southern Sweden. Geologiska Föreningen i Stockholm Förhandlingar 138, 336-354, https://doi.org/10.1080/11035897.2015.1055510. 
Talling, P. J. 2021: Fidelity of turbidites as earthquake records. Nature Geoscience 14, 113-116.

https://doi.org/10.1038/s41561-021-00707-2.

Talwani, M. \& Eldholm, O. 1972: The continental margin off Norway: A geophysical study. Geological Society of America Bulletin 83, 3573-3606.

Talwani, P. 2017: On the nature of intraplate earthquakes. Journal of Seismology 21, 47-68. https://doi.org/10.1007/s10950-016-9582-8.

Tappin, D.R. 2010: Submarine mass failures as tsunami sources: their climate control. Philosophical Transactions Royal Society A 368, 2417-2434. https://doi.org/10.1098/rsta.2010.0079.

Tingay, M., Manga, M., Rudolph, M.L. \& Davies, R. 2018: An alternative review of facts, coincidences and past and future studies of the Lusi eruption. Marine and Petroleum Geology 95, 345-361. https://doi.org/10.1016/j.marpetgeo.2017.12.031.

Tjåland. N. \& Ottemöller, L. 2018: Evaluation of seismicity in the Northern North Sea. Norwegian National Seismic Network, Technical Report No 29, 21 pp.

Tuffen, H. \& Betts R. 2010: Volcanism and climate: chicken and egg (or vice versa). Philosophical Transactions Royal Society A 368, 2585-2588. https://doi.org/10.1098/rsta.2010.0064.

Urlaub, M., Talling, P.J. \& Masson, D.G. 2013. Timing and frequency of large submarine landslides: Implications for understanding triggers and future geohazard. Quaternary Science Reviews 72, 63-82. https://doi.org/10.1016/j.quascirev.2013.04.020.

Urlaub, M., Talling, P.J., Zervos, A. \& Massson, D. 2015: What causes large submarine landslides on low gradient $(<20)$ continental slopes with slow $(\sim 0.15 \mathrm{~m} / \mathrm{ky})$ sediment accumulation? Journal of Geophysical Research 120, 6722-6739. https://doi.org/10.1002/2015JB012347.

Valagussa, A., Marc, O., Frattinia, P. \& Crosta G.B. 2019: Seismic and geological controls on earthquake-induced landslide size. Earth and Planetary Science Letters 506, 268-281.

https://doi.org/10.1016/j.epsl.2018.11.005.

Vasskog, K., Waldmann, N., Bondevik, S., Nesje, A., Chapron, E. \& Ariztegui, D. 2013: Evidence for Storegga tsunami run-up at the head of Nordfjord, western Norway. Journal of Quaternary Science 28, 391-402. https://doi.org/10.1002/jqs.2633.

Vestly, M.F. 2017: Earthquake triggered submarine slides in Norway. Master of Science thesis, University of Bergen, Norway, 118pp.

Vest $\varnothing$ I, O. 2006: Determination of postglacial land uplift in Fennoscandia from levelling, tide-gauge, and continuous GPS stations using least squares collocation. Journal of Geodesy 80, 248-258.

https://doi.org/10.1007/s00190-006-0063-7.

Vestøl, O., Ågren, J., Steffen, H., Kierulf, H. \& Tarasov, L. 2019: NKG2016LU: a new land uplift model for Fennoscandia and the Baltic Region. Journal of Geodesy 93, 1759-1779.

https://doi.org/10.1007/s00190-019-01280-8. 
Vorren, T.O., Laberg, J.S., Blaume, F., Dowdeswell, J.A., Kenyon, N.H., Mienert, J., Rumohr, J. \& Werner, F. 1998: The Norwegian-Greenland Sea continental margins: Morphology and Late Quaternary sedimentary processes and environment. Quaternary Science Reviews 17, 273-302. https://doi.org/10.1016/S0277-3791(97)00072-3.

Wanner, H. \& 17 others 2008: Mid- to Late Holocene climate change: an overview. Quaternary Science Reviews 27, 1791-1828. https://doi.org/10.1016/j.quascirev.2008.06.013.

Waage, M., Portnov, A., Serov, P., Bünz, S., Waghorn, K.A., Vadakkepuliyambatta, S., Mienert, J. \& Andreassen, K. 2019: Geological control on fluid flow and gas hydrate pingo development on the Barents Sea margin. Geochemistry, Geophysics, Geosystems 2019. 20, 630-650. https://doi.org/10.1029/2018GC007930.

Wagner, B., Bennike, O., Klug, M. \& Cremer, H. 2006: First indication of Storegga tsunami deposits from East Greenland. Journal of Quaternary Science 22, 321-325. https://doi.org/10.1002/jqs.1064.

Wahlström, R. 1993: Fennoscandian seismicity and its relation to the isostatic rebound. Global and Planetary Change 8, 107-112. https://doi.org/10.1016/0921-8181(93)90018-J.

Wahlström, R. \& Kulhánek O. 1983: The Lansjärv fault - seismically active or dead? Geologiska Föreningen i Stockholm Förhandlingar 105, 334. https://doi.org/10.1080/11035898309454570.

Wang H., Crutchley G.J. \& Stern T., 2017: Gas hydrate formation in compressional, extensional and un-faulted structural settings - Examples from New Zeeland's Hikurangi margin. Marine and Petroleum Geology 88, 69-80. https://doi.org/10.1016/j.marpetgeo.2017.08.001.

Watkinson, I.M. \& Hall, R. 2019: Impact of communal irrigation on the 2018 Palu earthquake-triggered landslides. Nature Geosciences 12, 940-945. https://doi.org/10.1038/s41561-019-0448-x.

Wessel, P., Luis, J.F., Uieda, L., Scharroo, R., Wobbe, F., Smith, W.H.F. \& Tian, D. 2019: The Generic Mapping Tools version 6. Geochemistry, Geophysics, Geosystems 20, 5556-5564, https://doi.org/10.1029/2019GC008515.

Wilson, P. 2009: Storurdi: A late Holocene rock-slope failure (stürzström) in Jotunheimen, southern Norway. Geografiska Annaler A 91, 47-58. https://doi.org/10.1111/j.1468-0459.2009.00352.x.

Wu, P., Johnston, P. \& Lambeck, K. 1999: Postglacial rebound and fault instability in Fennoscandia. Geophysical Journal International 139, 657-670. https://doi.org/10.1046/j.1365-246x.1999.00963.x.

Yanchilina, A.G. \& 11 others 2018: Exploring the methane gas seepage in the California borderland. Eos 98, 34-38. https://doi.org/10.1029/2017EO087843.

Yelisetti, S., Spence, G.D. \& Riedel, M. 2014: Role of gas hydrates in slope failures on frontal ridge of northern Cascadia margin. Geophysical Journal International 199, 441-458.

https://doi.org/10.1093/gji/ggu254.

You, K., Flemings, P.B., Malinverno, A., Collett, T.S. \& Darnell, K. 2019: Mechanisms of methane hydrate formation in geological systems. Reviews of Geophysics 57, 1146-1196.

https://doi.org/10.1029/2018RG000638. 